\title{
Fact or Fiction: The Legal Construction of Immigration Removal for Crimes
}

\author{
Maureen A. Sweeney ${ }^{\dagger}$
}

Thousands of long-term legal permanent residents are removed from the United States each year because they have been convicted of criminal offenses, many quite minor. These removals occur without any of the constitutional safeguards that generally protect criminal defendants. Immigration authorities rely on cases asserting that such removals are not punishment for crime, but rather remedial sanctions and merely collateral consequences of conviction.

This Article challenges those conclusions. It argues that their factual and doctrinal foundation has disintegrated over the last twenty years. Farreaching changes in immigration law and enforcement have rendered removal for many crimes a definite, immediate and largely automatic effect on the range of the defendant's punishment-that is, the direct consequence of a conviction. As such, under the current framework, the state should impose removal only subject to the same constitutional protections that apply to criminal prosecutions. As a practical matter, this would mean that a noncitizen defendant's guilty plea (and waiver of the Sixth Amendment right to trial) could only be considered knowing and voluntary if the defendant understood the immigration consequences of the plea, and that effective assistance of counsel would require advice about those consequences. In addition, under the Eighth Amendment, removal could only be imposed when it was not so disproportionate to the underlying crime as to be considered cruel and unusual punishment. While removal has essentially become an additional criminal sanction for noncitizens, this Article argues that it is not particularly effective or appropriate. The Article thus advocates a deep revision of immigration laws to restore removal as a sanction imposed in the exercise of discretion on those whose criminal offenses outweigh their ties to

\footnotetext{
$\uparrow$ Visiting Assistant Law School Professor, University of Maryland School of Law; J.D. Yale Law School, 1989; B.A. Wesleyan University, 1984. The Author wishes to thank the many people who helped in the researching and editing of this Article and who encouraged the Author, including research assistants Katrin Hussman and Maureen Contreni; research fellow Alice Johnson; research librarian Jenny Smith Rensler; my administrative assistant, Irvin Brooms; my colleagues Barbara Bezdek, Brenda Bratton Blom, Richard Boult, Michael Milleman, Michael Pinard, David Super, and Ellen Weber; David Chavkin and the many generous participants in the Mid-Atlantic Clinical Theory and Practice Workshop, especially Claire Smearman; and Fritz Bauerschmidt, my oldest academic friend and inspiration. Thanks also to my children, Thomas, Sophie, and Denis, for the days and evenings they did without me while this Article was being written.
} 
the United States and the hardship they and their community would suffer if they were deported.

Introduction 48

I. The Immigration Consequences of Convictions ..........................................52

A. The Courts............................................................................................. 52

1. Remedial and Collateral Consequences of Convictions Generally. 52

2. The Nature of Immigration Consequences 54

B. The Literature on Collateral Consequences in Immigration ......... 55

1. The Literature on Collateral Consequences Generally..............55

2. The Literature on Removal as a Consequence of Conviction

II. The Historical Legal Context for the Development of the

Jurisprudence of Immigration Consequences ......................................... 60

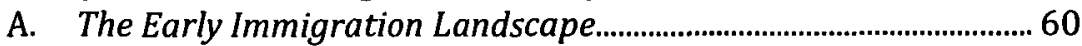

B. The Fact-Based Analysis of the Early Courts .....................................62

C. Changes to the Immigration Landscape .............................................. 63

III. The Directness of Immigration Consequences in the Current Legal

Framework

A. Removal as a Punitive Sanction ........................................................68

B. Removal as an Automatic Sanction for Aggravated Felony Convictions.

C. Removal as a Definite and Immediate Sanction ............................... 71

D. Removal as a Sanction Imposed Without Independent Due

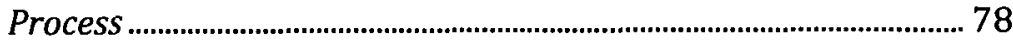

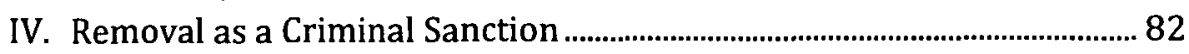

A. Implications of Acknowledging Removal as Punishment for

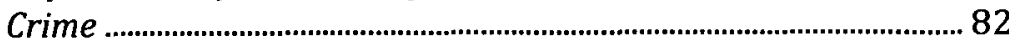

B. Is Removal an Effective and Appropriate Sanction for Crime? ... 83 Conclusion. 87

Introduction

The greatest joy and purpose of literary fiction is to tell us the truth. Successful works of fiction use the techniques of invention to reveal deep realities about our private and communal lives, the meaning of existence, and the textures of human love, forgiveness, absurdity, humor, and hope. ${ }^{1}$

1 Historical examples of fiction that helped tell important truths by portraying fictionalized realities include HARPER LEE, TO KILL A MOCKINGBIRD (1960), which depicts racism in the Jim Crow South; TONI MORRISON, BELOVED (1987), which puts a personal face on slavery; JOHN STEINBECK, THE GRAPES OF WRATH (1939), which describes the trials of refugees from the Oklahoma dust bowl of the 1930s; and HARRJET BEEChER STOWE, UNCLE TOM'S CABIN (Philip Van Doren Stern 
There are instances where legal fictions serve the same important purpose. Legal adoption of a child, for example, goes against our biological understanding of parenthood and creates the legal construct of a parental relationship between two biologically unrelated people. This is a "fiction" in that it has no biological basis, but it speaks of and gives legal solidity to the very real parental relationship that does exist between an adoptive parent and her child. The legal "fiction" reflects the deeper reality.

Some legal fictions, though, serve more to obscure reality than to reveal it. Such is the case with the theoretical construct of removal for criminal activity. Under current immigration law, a noncitizen who is convicted of any one of a large array of criminal offenses (some serious but many others quite minor) is rendered removable and disqualified from relief from removal solely because of that crime. Over the last decade, immigration authorities deported tens of thousands of lawful permanent residents as a result of such criminal conduct. Particularly for those with spouses and children in this country, the consequences of removal were far more severe than the terms of their criminal sentences. However, courts have consistently held that removal is not punishment for crime but is instead a remedial civil sanction and a collateral, rather than direct, consequence of a conviction. This theoretical characterization of removal developed many decades ago in the context of the very different immigration law that existed then. It no longer corresponds in any meaningful way to the realities of immigration law and enforcement, which have changed radically in the last two decades. It has become a fiction that obscures rather than reflects any level of reality.

As a result of this legal construct, however, the sanction of removal, severe and automatic as it has become, has been allowed to attach to criminal convictions outside the protections of the Constitution that generally apply to punishment for criminal activity. ${ }^{2}$ Removal for crimes is now imposed with fewer procedural protections than ever and with no concern for its proportionality to the underlying criminal activity. The United States Supreme Court recently acknowledged the constitutional

ed., Paul S. Eriksson Inc. 1964) (1852), which portrays the evils of slavery. Marilynne Robinson's recent diptych of novels is a beautiful example of fiction eloquently telling truths of family. forgiveness, hope, and the beauty of seemingly insignificant and forgotten people and places. See MARILYNNE ROBINSON, GILEAD (2004); MARILYNNE ROBINSON, HOME (2008).

2 The Sixth Amendment, for example, requires that any waiver of the constitutional right to trial be voluntary and "knowing," which requires, in turn, that the defendant understand the charges against him or her and the potential consequences of the conviction. Brady v. United States, 397 U.S. 742, 755 (1970); Boykin v. Alabama, 395 U.S. 238, 242 (1969). However, this requirement applies only to the "direct," punishment-related consequences of a conviction and not to "collateral" consequences. See, e.g., United States v. Crowley, 529 F.2d 1066, 1072 (3d Cir. 1976); Cuthrell v. Director, 475 F.2d 1364, 1366 (4th Cir. 1973). Deportation has consistently been held to be a collateral civil sanction, and defendants need not be advised of the possibility that they may be deported in order for their waiver of constitutional rights to be knowing and voluntary. See, e.g., Santos-Sanchez v. United States, 548 F.3d 327, 336 (5th Cir. 2008). 
import of these issues when it granted certiorari in a case involving the question of whether the Sixth Amendment right to effective assistance of counsel requires criminal defense attorneys to provide accurate advice about the fact that a proposed plea agreement may or will lead to the defendant's removal. ${ }^{3}$ Even if the Court answers in the affirmative, however, a whole host of other vital procedural rights will continue to be denied legal immigrants accused of crimes as a result of this legal construct.

An understanding of removal as punishment is certainly the reality lived by many criminal defendants who deal with immigration consequences in the context of plea negotiations. These lawful permanent residents (and other legally authorized individuals such as asylees and refugees) often accept longer terms of actual incarceration, extensions of parole or supervised release, and other negative terms in plea agreements in exchange for avoiding conditions that could prejudice their immigration status. ${ }^{4}$ They are willing to accept additional incarceration and probation, which are universally acknowledged to be punishment, for protection from removal, the sanction they consider more serious. ${ }^{5}$

Yet courts at all levels have nearly universally rejected attempts by noncitizens facing deportation to claim the constitutional protections accorded to those facing punishment for crimes. ${ }^{6}$ The courts have done so by relying on longstanding precedent which holds that removal is not punitive but is rather a remedial sanction designed to end an ongoing violation of civil immigration law, and that it is the indirect or collateral consequence of a conviction rather than direct punishment for the underlying crime.

For moral and doctrinal reasons, this legal construction of removal has become untenable, and the time has come to reexamine it. The human cost of our current legal construction of removal is extremely high. Tens of thousands of individuals are removed for crimes each year, many after entering guilty pleas without any knowledge that their plea would lead directly to their removal and permanent banishment from the United

3 Commonwealth v. Padilla, 253 S.W.3d 482 (Ky. 2008) (posing the questions whether criminal defense counsel is required to advise a defendant of the automatic sanction of deportation for an aggravated felony conviction and whether affirmative misadvice from criminal defense counsel about deportation consequences constitutes ineffective assistance of counsel under the Sixth Amendment), cert. granted, 129 S. Ct. 1317 (2009).

4 Telephone Interviews and E-mail Correspondence with Joanna Silver, Fed. Pub. Defender, Dist. of Md. (Jan. 9, 2009); Laura Harper, Fed. Pub. Defender, N. Dist. of Tex., Dallas Div. Uan. 7, 2009); Frank Mangan, Fed. Pub. Defender, S. Dist. of Cal., San Diego Div. (Jan. 7, 2009) (on file with The Yale Journal on Regulation).

5 ld.

6 See, e.g., Nikolaev v. Weber, 705 N.W.2d 72, 76 (S.D. 2005) ("'[T] he overwhelming majority of courts to have addressed the question... have held that deportation is a collateral consequence..."' (quoting State v. Zarate, 651 N.W.2d 215, 222 (Neb. 2002))); see also United States v. Nagaro-Garbin, 653 F. Supp. 586, 589 (E.D. Mich. 1987). 
States, with no possibility for deviation, equity, or mercy. Many of those removed are lawful permanent residents of the United States who have parents, children, spouses, and other immediate family members who are themselves United States citizens or lawful permanent residents. The Department of Homeland Security (DHS) recently reported that it had deported more than 100,000 parents of children who are U.S. citizens in the ten years prior to 2007.7 These families are faced with a life-shattering decision: should they acquiesce to the permanent break-up of their family through the removal of one of their members, or should they uproot the entire family and move permanently to a country that may have never been home to any of them except the one being deported, where none of them may speak the language, where medical care may be lacking, and where they may have no support network and few educational, social, or job prospects? Even those permanent residents without immediate family in the United States often have long residence here and face the loss of deeply rooted lives amid communities, workplaces, businesses, churches, and friends. The impact of removal is profound; as the United States Supreme Court wrote in $\mathrm{Ng}$ Fung Ho v. White, removal may result in "loss of both property and life; or of all that makes life worth living." 8

This Article will argue that the current legal construction of removal for crimes was built many years ago on statutory and factual underpinnings that have since disintegrated. The legal and enforcement framework that gave rise to the construction of deportation as "remedial" and "collateral" simply no longer exists, and current realities of immigration law and enforcement neither support nor justify the prevailing legal construction. Part I reviews the state of the law and the literature with regard to collateral consequences generally and deportation specifically. Part II lays out the historical legal context in which the jurisprudence developed and the changes to the legal and enforcement framework of immigration over the last two decades. Part III analyzes the current legal and factual framework to find that removal for such criminal convictions is punitive rather than remedial in nature and is the direct functional consequence of a conviction. Part IV looks at the practical and constitutional implications of concluding that removal is the direct and punitive consequence of an aggravated felony conviction and poses the question whether automatic removal is an effective and appropriate sanction for crime. The Conclusion proposes some possible resolutions to the constitutional dilemma raised by the current system.

7 Michael Falcone, 100,000 Parents of Citizens Were Deported over 10 Years, N.Y. TIMES Feb. 14, 2009, at A16.

8259 U.S. 276, 284 (1922). 
I. The Immigration Consequences of Convictions

\section{A. The Courts}

\section{Remedial and Collateral Consequences of Convictions Generally}

Throughout the twentieth century, the courts developed a wideranging jurisprudence regarding the relationship between criminal proceedings and various consequences that result from criminal convictions. This jurisprudence has often focused on whether criminal defendants have the right to be advised of, and represented in proceedings regarding, the imposition of these consequences. The relevant line of cases arose in the context of a variety of consequences, including discretionary loss of "good time" credit, ${ }^{9}$ parole eligibility, ${ }^{10}$ civil commitment to a mental health facility, ${ }^{11}$ concurrent sentencing, ${ }^{12}$ loss of voting rights, ${ }^{13}$ and maximum possible incarceration. ${ }^{14}$ Courts have varied in their analysis of which consequences warrant constitutional protections and which do not, generally finding defendants to be entitled to the constitutional protections of criminal proceedings only when they have found a consequence of conviction to be punitive (rather than remedial) in nature and the direct (rather than collateral) consequence of the conviction. ${ }^{15}$ These principles have come to be known as the collateral consequences doctrine.

In applying the doctrine, courts have looked first to the stated and effective purpose of a sanction to determine whether it is punitive or remedial in nature. ${ }^{16}$ While the stated purpose is not necessarily dispositive and courts can consider a strongly punitive effect, ${ }^{17}$ the Supreme Court has held that courts should reject the stated legislative intent "only where a party challenging the statute provides 'the clearest proof' that 'the statutory scheme [is] so punitive either in purpose or effect

9 Hutchison v. United States, 450 F.2d 930, 931 (10th Cir. 1971).

10 Paige v. United States, 443 F.2d 781 (4th Cir. 1971); Yoswick v. State, 700 A.2d 251 (Md. 1997).

11 Cuthrell v. Director, 475 F.2d 1364 (4th Cir. 1973).

12 Tindall v. United States, 469 F.2d 92 (5th Cir. 1972).

13 Meaton v. United States, 328 F.2d 379 (5th Cir. 1964).

14 Combs v. United States, 391 F.2d 1017 (9th Cir. 1968); Pilkington v. United States, 315 F.2d 204, 210 (4th Cir. 1963).

15 See, e.g., Kansas v. Hendricks, 521 U.S. 346, 369 (1997) ("Our conclusion that the Act is nonpunitive thus removes an essential prerequisite for both Hendricks' double jeopardy and $e x$ post facto claims.").

16 Trop v. Dulles, 356 U.S. 86, 96 (1958).

17 Hendricks, 521 U.S. at 361. 
as to negate [the State's] intention' to deem it 'civil."'18 As a practical matter, courts have been very willing to accept legislative statements of remedial effect. 19

With regard to the direct versus collateral determination, courts have generally applied a practical standard. Some courts simply state in conclusory fashion that a consequence is direct or collateral. ${ }^{20}$ Other courts acknowledge the difficulty of making the distinction, but then rely on the determination made in prior cases rather than engaging in any independent analysis. ${ }^{21}$ A relatively small number of courts apply a more substantive analysis. These courts have generally based their consideration on whether the consequence is punitive in nature and the practical realities of the procedural relationship between entry of the conviction and imposition of the consequence.

Courts have applied different standards, but the most robust and widely applied standard is that put forth by the U.S. Court of Appeals for the Fourth Circuit in 1973, in Cuthrell v. Director, ${ }^{22}$ and adopted by six other federal circuit courts of appeals. ${ }^{23}$ The court in Cuthrell stated that the directness of a consequence turned on whether it "represent[ed] a definite, immediate and largely automatic effect on the range of the defendant's punishment." 24 That case involved the involuntary commitment of a defendant for treatment in a state hospital as a "defective delinquent." The court found that such commitment was not a direct consequence of conviction, noting that the commitment proceeding that followed the defendant's conviction was a separate civil proceeding in which the defendant "would be afforded counsel and all due process rights," and that the outcome was far from certain, depending on the testimony and conclusions of trained experts and the independent judgment of a judge or jury. ${ }^{25}$ In short, "[c]ommitment thus depended not directly on the defendant's plea but on a subsequent, independent civil

18 Id. (quoting United States v. Ward, 448 U.S. 242, 248-49 (1980)).

19 See, e.g., Smith v. Doe, 538 U.S. 84, 105 (2003); Hendricks, 521 U.S. at 368-69; Turner v. Glickman, 207 F.3d 419, 428-30 (7th Cir. 2000).

20 See, e.g., Meaton v. United States, 328 F.2d 379, 381 (5th Cir. 1964) ("There was no abuse of discretion in the refusal of the court to grant leave to withdraw the plea of guilty because the appellant failed to understand the collateral effects such as the loss of civic rights.").

21 See, e.g., United States v. Russell, 686 F.2d 35, 38-39 (D.C. Cir. 1982) ("The distinction between a collateral and a direct consequence of a criminal conviction, like many of the lines drawn in legal analysis, is obvious at the extremes and often subtle at the margin.").

22475 F.2d 1364 (4th Cir. 1973).

23 See Steele v. Murphy, 365 F.3d 14, 17 (1st Cir. 2004); United States v. Littlejohn, 224 F.3d 960, 965 (9th Cir. 2000); United States v. Kikuyama, 109 F.3d 536, 537 (9th Cir. 1997); Parry v. Rosemeyer, 64 F.3d 110, 114 (3d Cir. 1995); King v. Dutton, 17 F.3d 151, 155 (6th Cir. 1994); United States v. U.S. Currency in Amount of $\$ 228,536.00,895$ F.2d 908, 916 (2d Cir. 1990); George v. Black, 732 F.2d 108, 110 (8th Cir. 1984); see also United States v. Lott, 630 F. Supp. 611, 612 (E.D. Va. 1986).

24 Cuthrell, 475 F.2d at 1366.

25 Id. 
trial' $^{26}$ of substance. The court emphasized the lack of certainty in the outcome of the post-conviction commitment process, pointing out that (1) not all those convicted were ordered evaluated for delinquency; (2) of those evaluated, one-third were not recommended for commitment; and (3) of those recommended, one-fifth prevailed at jury trial. ${ }^{27}$ In addition, the court observed that the purpose of the commitment was not punishment but treatment and rehabilitation of an individual with a mental disorder. ${ }^{28}$

\section{The Nature of Immigration Consequences}

Over the years, many courts have addressed the specific question of the implications in the criminal procedural context of a deportation that is triggered solely by the outcome of that criminal proceeding. These courts have generally relied on the characterization of deportation as a remedial sanction and have also virtually universally held that deportation is a collateral consequence of a conviction; for these reasons, a criminal defendant's constitutional protections do not attach to proceedings relating to the immigration consequences of a conviction. ${ }^{29}$

The Supreme Court first held that deportation proceedings were civil and remedial in nature, rather than punitive, in the 1893 case of Fong Yue Ting $v$. United States. ${ }^{30}$ At that time, immigration law was in its infancy, and the only provisions allowing for deportation related to the failure of individuals to comply with the terms of their admission to the country. There were no deportation provisions triggered by post-entry conduct such as the commission of a crime. ${ }^{31}$ It was in this context that the Supreme Court held deportation to be a civil, regulatory sanction whose purpose was not to punish but to remedy an ongoing violation of the conditions under which a person had been admitted to the United States. ${ }^{32}$

26 Id.

27 Id. at 1367.

28 Id.

29 See, e.g., United States v. Amador-Leal, 276 F.3d 511, 516-17 (9th Cir. 2002), cert. denied, 535 U.S. 1070 (2002); United States v. Romero-Vilca, 850 F.2d 177, 179 (3d Cir. 1988) ("[W]e hold that potential removal is a collateral consequence of a guilty plea."); State v. Muriithi, 46 P.3d 1145, 1155 (Kan. 2002); People v. DeJesus, 819 N.Y.S.2d 442, 445 (Crim. Ct. 2006); Nikolaev v. Weber, 705 N.W.2d 72, 76 (S.D. 2005); Valle v. State, 132 P.3d 181, 184 (Wyo. 2006).

30149 U.S. 698, 730 (1893).

31 Daniel Kanstroom, Deportation, Social Control, and Punishment: Some Thoughts About Why Hard Laws Make Bad Cases, 113 HARV. L. REV. 1889, 1908-09 (2000).

32 Fong Yue Ting, 149 U.S. at 730 ("The order of deportation is not a punishment for crime. It is not a banishment, in the sense in which that word is often applied to the expulsion of a citizen from his country by way of punishment. It is but a method of enforcing the return to his own country of an alien who has not complied with the conditions upon the performance of which the government of the nation, acting within its constitutional authority and through the proper departments, has determined that his continuing to reside here shall depend. He has not, therefore, been deprived of life, liberty or property, without due process of law; and the provisions 
As such, deportation could be imposed in proceedings that did not comport with the protections that the Fourth, Sixth, and Eighth Amendments provide to criminal defendants. ${ }^{33}$

This doctrine has remained the cornerstone of this jurisprudence since the nineteenth century, despite many changes to the law and procedures regarding deportation during the twentieth century. In 1999, the Supreme Court reiterated this holding in the case of Reno v. AmericanArab Anti-Discrimination Committee, ${ }^{34}$ in which Justice Scalia's majority opinion states without further elaboration:

Even when deportation is sought because of some act the alien has committed, in principle the alien is not being punished for that act (criminal charges may be available for that separate purpose) but is merely being held to the terms under which he was admitted. And in all cases, deportation is necessary in order to bring to an end an ongoing violation of the United States law. 35

\section{B. The Literature on Collateral Consequences in Immigration}

Commentators have challenged both the use of the direct versus collateral distinction as the deciding factor in determining constitutional protections as a general matter and the characterization of deportation as a collateral remedial sanction.

\section{The Literature on Collateral Consequences Generally}

A chorus of commentators has analyzed the appropriateness, constitutionality, and wisdom of the growing body of collateral consequences of criminal convictions, including loss of civil rights, ineligibility for public benefits, employment-related restrictions, and ineligibility for jury service. ${ }^{36}$ These commentators have analyzed collateral consequences in light of the traditional purposes and

of the Constitution, securing the right of trial by jury, and prohibiting unreasonable searches and seizures, and cruel and unusual punishments, have no application.").

33 Id.

34525 U.S. 471 (1999).

35 Id. at 491.

36 For a good summary of the legal issues regarding collateral consequences, see generally Michael Pinard, An Integrated Perspective on the Collateral Consequences of Criminal Convictions and Reentry Issues Faced by Formerly Incarcerated Individuals, 86 B.U. L. REV. 623, 634-47 (2006) [hereinafter Pinard, Integrated Perspective]. For a summary of the various analyses and commentaries, see $i d$. at 658-66; and Michael Pinard, The Logistical and Ethical Difficulties of Informing Juveniles About the Collateral Consequences of Adjudications, 6 NEV. L.J. 1111, 1112 (2006). 
justifications of punishment, ${ }^{37}$ challenged the legal distinction between criminal and civil penalties, and contested the use of the distinction to justify the absence of substantive procedural protections relating to these rights in criminal proceedings. ${ }^{38}$ A survey of state court judges found that, with regard to collateral consequences generally, nearly four out of five judges believed that it was unclear whether their states' collateral consequences were punitive or remedial in purpose, ${ }^{39}$ although they recognized the collateral consequences' substantial punitive effects. ${ }^{40}$

The American Bar Association (ABA) has also studied the issue of collateral consequences extensively and has issued a set of Standards on Collateral Sanctions and Discretionary Disqualification of Convicted Persons ("Standards"). ${ }^{41}$ The Standards proceed from the premise that "it is neither fair nor efficient for the criminal justice system to label significant legal disabilities and penalties as 'collateral' and thereby give permission to ignore them in the process of criminal sentencing." 42 Thus, rather than arguing the specifics of classification of consequences as direct or collateral, the Standards start from the premise that the distinction should not necessarily dictate the treatment of those consequences in criminal proceedings. The Standards are aimed at the integration of all legal consequences of convictions (regardless of their traditional characterization) into the criminal sentencing system. The Standards thus seek to ensure that any sanction is appropriate to the conduct underlying the conviction, that all actors are aware of all sanctions, and that a court or administrative body is empowered to waive or modify any sanction where appropriate. ${ }^{43}$ In a case that is currently pending before the Supreme Court, 44 the $\mathrm{ABA}$ has used the Standards to argue specifically in the removal context that criminal defense counsel has a duty to advise any noncitizen defendant of the immigration consequences of conviction when that defendant is considering whether to plead guilty. 45

37 Nora V. Demleitner, Preventing Internal Exile: The Need for Restrictions on Collateral Sentencing Consequences, 11 STAN. L. \& PoL'Y REV. 153, 160-61 (1999), cited in Pinard, Integrated Perspective, supra note 36 , at 659.

38 See Pinard, Integrated Perspective, supra note 36, at 659-60 (citing various scholarly works).

39 Alec C. Ewald \& Marnie Smith, Collateral Consequences of Criminal Convictions in American Courts: The View from the State Bench, 29 JUST. SYS. J. 145, 155 (2008).

$40 \quad$ Id. at 161.

41 Am. Bar ass'N, ABA Standards for Criminal Justice: Collateral Sanctions and DisCRETIONARY DISQUALIFICATION OF CONVICTED PERSONS (3d ed. 2004) [hereinafter ABA STANDARDS ON COLLATERAL SANCTIONS].

42 Id, at 11.

43 Id. at $12 \cdot 13$.

44 Padilla v. Kentucky, 129 S. Ct. 1317 (2009).

45 Brief of the American Bar Ass'n as Amicus Curiae in Support of Petitioner, Padilla v. Kentucky, 129 S. Ct. 1317 (2009) (No. 08-651), 2009 WL 1567355. 


\section{The Literature on Removal as a Consequence of Conviction}

Though the conventional wisdom of case law is unwavering in stating that deportation is not punishment for wrongdoing, ${ }^{46}$ a number of commentators and scholars have recently reexamined the history and contemporary legal framework of removal for crimes and have argued that removability based on criminal convictions constitutes punishment for wrongdoing. 47

Daniel Kanstroom has pointed out the significance of the distinction between two types of removal provisions in our law: those "border control" provisions related to regulation of entry and exit at borders, and those provisions related to "social control"-that is, provisions that relate to individuals' post-entry behavior. ${ }^{48}$ Border control provisions relate to requirements for and conditions on admissions and authorized stays in the country, including such requirements as a valid visa for entry and adherence with visa conditions (such as enrollment in school or refraining from employment). Kanstroom points out that constitutional questions about the nature of the sanction of deportation first arose in the context of the enforcement of border control provisions regulating conditions for entry, and the courts reasonably held that such deportations were regulatory in nature and not intended to punish the individual for any wrongful conduct. ${ }^{49}$ In this context, the Supreme Court developed a doctrinal structure basing the government's power to deport on its plenary power to regulate immigration, limited only by basic principles of procedural due process. ${ }^{50} \mathrm{~A}$ key principle of this structure is that deportation is a remedial action designed to correct the ongoing violation of a regulatory requirement, such as the requirement of a valid visa to authorize entry and presence in the United States, or the requirement that the holder of a student visa be enrolled full-time in an American school.

This doctrinal structure has stood from those early days and has been used to justify a broad deportation power, despite the development of a significant body of "social control" deportation provisions used to deport lawful permanent residents and others based solely on post-entry conduct

46 See Stephen H. Legomsky, The New Path of Immigration Law: Asymmetric Incorporation of Criminal Justice Norms, 64 WASH. \& LEE L. REV. 469, 512 (2007) (arguing that decisions relying on formalistic characterization of deportation as a "civil" proceeding rather than punitive are "long on citation of precedent and short on independent reasoning").

47 See Kanstroom, supra note 31; Legomsky, supra note 46, at 512; Robert Pauw, A New Look at Deportation as Punishment: Why at Least Some of the Constitution's Criminal Procedure Protections Must Apply, 52 ADMIN. L. REV. 305 (2000); Juliet P. Stumpf, Penalizing Immigrants, 18 FED. SENT'G REP. 264 (2006).

48 Kanstroom, supra note 31, at 1906.

49 Id. at 1901, 1908; see Fong Yue Ting v. United States, 149 U.S. 693 (1893).

50 Kanstroom, supra note 31, at 1910. 
in no way related to the conditions of their admission or authorized stay. ${ }^{51}$ Kanstroom argues that these social control provisions are conceptually distinct from border control provisions and are not regulatory in the same way that justified earlier analysis of deportation. Rather, social control deportation provisions do, in fact, constitute punishment for the postentry conduct being sanctioned. As such, they should be subject to constitutional protections relating to punishment. 52

Stephen Legomsky argues that the stated "remedial" purpose of deportation-removing the offender from the community-is not, by its nature, remedial at all, but rather one of the classic purposes of punishment, the incapacitation of the offender. ${ }^{53}$ Legomsky and other commentators also argue that removal as applied to otherwise lawful residents who are convicted of criminal wrongdoing serves the classic penal purposes of retribution and deterrence of others. ${ }^{54}$

Other commentators, including Robert Pauw, have also observed the move of modern courts away from an "all-or-nothing" distinction between civil proceedings (which result in purely remedial sanctions) and criminal proceedings (which result in punishment), and the courts' resulting willingness to acknowledge punishment imposed in some circumstances in civil proceedings, and to accord some constitutional protections to such proceedings. ${ }^{55}$ The Supreme Court has in recent decades held that sanctions imposed in civil proceedings must be justified by a legitimate remedial government interest and must be proportionate to that purpose. ${ }^{56}$ If they cannot be justified as proportionately serving a remedial purpose, they will be seen as punitive and subject to the Constitution's limitations on the imposition of punishment. ${ }^{57}$ While the Court has been less than entirely consistent or clear over the years on how to analyze punitive intent, ${ }^{58}$ it has recognized a principle of analysis that is

51 See, e.g., Reno v. Am.-Arab Anti-Discrimination Comm., 525 U.S. 471, 491 (1999).

52 Kanstroom, supra note 31, at 1935.

53 Legomsky, supra note 46 , at 514.

54 Id.; see also Pauw, supra note 47, at 328; Stumpf, supra note 47, at 265.

55 Pauw, supra note 47, at 316; see Kanstroom, supra note 31, at 1920.

56 United States v. Ursery, 518 U.S. 267 (1996) (holding that a civil in rem forfeiture action does not impose punishment and thus does not implicate the Double Jeopardy Clause); Dep't of Revenue v. Kurth Ranch, 511 U.S. 767 (1994) (finding that a tax on possession of illegal drugs, assessed after criminal penalty, could be considered punishment implicating the Double Jeopardy Clause); Austin v. United States, 509 U.S. 602, 621 (1993) (holding that a civil drug forfeiture action had the purpose of imposing punishment and was subject to Eighth Amendment limits).

57 Trop v. Dulles, 356 U.S. 86, 96 (1958) ("[I]f the statute imposes a disability for the purposes of punishment-that is, to reprimand the wrongdoer, to deter others, etc. -it has been considered penal. But a statute has been considered nonpenal if it imposes a disability, not to punish, but to accomplish some other legitimate governmental purpose."). For a discussion of the constitutional limitations that may apply if deportation is recognized as punishment, see Pauw, supra note 47 , at $337-44$.

58 Kanstroom, supra note 31 , at 1925-26. 
essentially functional and considers the actual impact of a sanction rather than simply its legislative label. ${ }^{59}$ The Court has recognized as punitive civil sanctions in cases involving civil drug forfeiture, ${ }^{60}$ civil fines for false medical expense claims, ${ }^{61}$ taxes on illegal drug possession, ${ }^{62}$ and in rem forfeiture. ${ }^{63}$

Pointing to the Court's willingness to look beyond the formalistic criminal versus civil label and to assess the actual effect of a sanction, Pauw and others have made the case for a functional analysis of the effect of removal on lawful permanent residents who are otherwise authorized to remain indefinitely in the United States. ${ }^{64}$ Recognizing the punitive effect of the sanction would allow for constitutionally based procedural protections for noncitizens in criminal proceedings. Lea McDermid has argued that the unique severity of the removal sanction and the increased likelihood of its imposition following recent statutory changes justify the abandonment of the collateral consequences doctrine as the linchpin for determining the appropriateness of constitutional protections. ${ }^{65} \mathrm{John} \mathrm{J.}$ Francis has also argued that the principles behind Rule 11(b) of the Federal Rules of Criminal Procedure, ${ }^{66}$ which seeks to ensure that any guilty plea is entered voluntarily and with knowledge of its consequences, and the constitutional case law require that defendants be aware of the possibility of removal, given its unique severity. ${ }^{67}$

The remainder of this Article will analyze the historical legal context in which courts first found deportation to be a remedial and collateral consequence of conviction, the current realities of immigration law and enforcement relating to convictions, and the implications of those realities for the analytical framework underpinning the jurisprudence.

59 Id.; Pauw, supra note 47, at 328.

60 Austin, 509 U.S. at 621.

61 United States v. Halper, 490 U.S. 435 (1989). In Hudson v. United States, the Court rejected the Double Jeopardy Clause analysis of Halper, but it did not overrule its finding that civil sanctions in civil proceedings may constitute punishment. Hudson v. United States, 522 U.S. 93, 96 (1997).

62 Dep't of Revenue v. Kurth Ranch, 511 U.S. 767, 779 (1994).

63 See United States v. Ursery, 518 U.S. 267 (1996).

64 Kanstroom, supra note 31, at 1928; Pauw, supra note 47, at 332.

65 Lea McDermid, Deportation Is Different: Noncitizens and Ineffective Assistance of Counsel, 89 CAL. L. REv. 741 (2001) (discussing whether courts should raise the standard on what qualifies as effective assistance of counsel in the immigration context).

66 FED. R. CRIM. P. 11(b).

67 John J. Francis, Failure to Advise Non-Citizens of Immigration Consequences of Criminal Convictions: Should This Be Grounds to Withdraw a Guilty Plea?, 36 U. MICH. J.L. REFoRM 691, 719 20 (2003). 
II. The Historical Legal Context for the Development of the Jurisprudence of Immigration Consequences

Many of the early decisions addressing the direct versus collateral distinction in immigration consequences took the standards of analysis developed for other consequences and applied them to the laws, procedure, and practical realities of immigration enforcement that existed at that time. ${ }^{68}$ Based on this analysis of the legal landscape of immigration, they concluded that deportation was not a direct consequence of a criminal conviction. In order to correctly understand the decisions from this period, it is important to have a good understanding of the legal and enforcement context of immigration law on which the courts based their analysis.

\section{A. The Early Immigration Landscape}

U.S. immigration law has long imposed significant consequences on certain criminal convictions. However, for many decades, through equally longstanding law, procedure, and practice, these consequences were also subject to uncertainties and vagaries of enforcement and open to amelioration through widely available discretionary waivers of deportability for those convicted of crimes. Since 1917, noncitizens who have committed crimes "involving moral turpitude" have been excludable from the United States. ${ }^{69}$ At the same time, however, immigration law has also provided a broad discretionary exception to such exclusion for longterm residents who could show that they deserved a second chance. ${ }^{70}$

Like the Immigration Act of 1917, the 1952 Immigration and Nationality Act (INA) mandated exclusion for immigrants convicted of crimes involving moral turpitude or drug trafficking. ${ }^{71}$ Also like the prior law, the INA in 1952 gave the Attorney General broad discretion to grant legal status to individuals notwithstanding their convictions, provided they had resided in the United States for seven years. ${ }^{72}$ This section 212 (c)

68 See, e.g., Daley v. State, 487 A.2d 320 (Md. Ct. Spec. App. 1985). In contrast, some courts considering the directness of deportation simply stated in conclusory fashion that deportation was a collateral consequence. See, e.g., United States v. Parrino, 212 F.2d 919, 921 (2d. Cir. 1954) ("[Deportability] is a liability which may, and in this case does, depend on a conviction of crime. But it is nonetheless a collateral consequence of conviction.").

69 Immigration Act of 1917, ch. 29, 39 Stat. 874, 875, cited in Immigration \& Naturalization Serv. v. St. Cyr, 533 U.S. 289, 294 (2001).

7039 Stat. at 878 . For a brief summary of the applicable provisions, see St. Cyr, 533 U.S. at 294.

71 See Immigration and Nationality Act, Pub. L. No. 82-414, 66 Stat. 163 (1952) [hereinafter INA].

7266 Stat. at 187; see also 8 U.S.C. $\$ 1182$ (c) (repealed 1996). 
waiver, named for its location in the INA, was also regularly used to waive deportation for lawful permanent residents of at least seven years. ${ }^{73}$

The accepted standard for granting section 212(c) relief was a weighing of the equities of the case. ${ }^{74}$ A court applying section 212 (c) had to weigh the negative factors (including the nature and underlying circumstances of any immigration violation or ground for exclusion; the nature, seriousness, and recency of any criminal convictions; and other evidence of an applicant's bad character) against the positive factors (including family ties in the United States; residence of long duration; age at entry; hardship to the family or the applicant if deported; employment history; property; military service; service to the community; evidence of rehabilitation; and other evidence of good character). The immigration judge was to balance the positive and adverse factors and decide on the record as a whole whether the applicant was deserving of a positive exercise of discretion. ${ }^{75}$

Relief under section 212 (c) was granted in a wide range of cases involving a wide range of convictions, even quite serious ones. In the period between 1989 and 1995, over ten thousand individuals were granted section 212 (c) relief. 76 More than half of all section 212(c) applications filed during that time period were granted. ${ }^{77}$ As a result, a broad expectation developed in the immigrant community that, even with a criminal conviction, an individual would have a chance to fight deportation by appealing to the discretion of an immigration judge. ${ }^{78}$ In addition, at the time of many of the early decisions about the directness of immigration consequences, immigration law provided for judicial recommendations against deportation (JRADs), which, if granted by a judge in a criminal proceeding, prohibited the federal government from using a conviction as the basis for deportation or exclusion. 79

Finally, at the time of these decisions, there was little coordination between the criminal and the immigration bureaucracies, and the enforcement of deportation or exclusion provisions against individuals with convictions was uneven at best. Many deportable individuals were

73 Matter of Silva, 16 I. \& N. Dec. 26, 30 (B.I.A. 1976) (adopting the position of Francis v. Immigration \& Naturalization Serv., 532 F.2d 268 (2d Cir. 1976)).

74 See In re Marin, 16 I. \& N. Dec. 581, 584-85 (B.I.A. 1978).

75 Id.

76 See Immigration \& Naturalization Serv. v. St. Cyr, 533 U.S. 289, 296 (2001) (citing Julie K. Rannik, The Anti-Terrorism and Effective Death Penalty Act of 1996: A Death Sentence for the 212(c) Waiver, 28 U. MIAMI INTER-AM. L. REV. 123, 150 n.80 (1996)).

77 Id.

78 This is the argument in Immigration \& Naturalization Service v. St. Cyr, in which the Supreme Court upheld retroactive eligibility for section 212 (c) relief based on criminal defendants having pled guilty with the expectation of section 212(c) eligibility in immigration proceedings. 533 U.S. at 325.

79 INA § 241(b), 66 Stat. at 208 (repealed 1990); 8 U.S.C. $§ 1251$ (b) (repealed 1990). 
able to remain in the United States for many years without threat of removal, as long as they did not bring themselves to the attention of the government by leaving and seeking to reenter the country or by applying for some immigration or naturalization benefit. 80

\section{B. The Fact-Based Analysis of the Early Courts}

Daley v. State, 81 a 1985 decision of the Maryland Court of Special Appeals, illustrates how many early courts applied the existing standards in the immigration context. The Daley court applied the Fourth Circuit's criteria from Cuthrell $v$. Director ${ }^{82}$ to determine whether immigration consequences were direct or collateral consequences of criminal convictions. The court's analysis in Daley is typical of the reasoning of other courts from the era, and it reveals the extent to which such courts grounded their decisions in the factual context of the landscape of immigration law that existed at the time of the decision.

The Daley court looked to the standard articulated in Cuthrell, which asked whether the consequence of a conviction "represents a definite, immediate and largely automatic effect on the range of the defendant's punishment." 83 The Daley court first observed that deportation arises in the context of a civil proceeding separate from the criminal proceeding. 84 The court next observed that deportation was "neither 'definite' nor 'largely automatic," referring specifically to the availability of discretionary relief including the section 212 (c) waiver which was then widely available to individuals with convictions. ${ }^{85}$ Finally, the court found that the deportation proceedings in the case before it were not necessarily "immediate," as the defendant only came to the attention of the immigration authorities when he attempted to reenter the country nearly two years after his guilty plea. ${ }^{86}$ The court rightly observed that, in the enforcement landscape of 1985, proceedings "might never have been instituted" against Mr. Daley had he not left the country, and held that deportation was a collateral consequence. ${ }^{87}$

80 For a detailed discussion of the profound problems in the enforcement of deportation against individuals with criminal convictions through the late 1990 s, see Peter H. Schuck \& John Williams, Removing Criminal Aliens: The Pitfalls and Promises of Federalism, 22 HARv. J.L. \& PUB. POL'Y 367 (1999).

81487 A.2d 320 (Md. Ct. Spec. App. 1985).

82475 F.2d 1364 (4th Cir. 1973).

83 Id. at 1366.

84 Daley, 487 A.2d at 322.

85 Id. This form of relief was repealed in the Illegal Immigration Reform and Immigrant Responsibility Act (IIRIRA) in 1996. See discussion infra Section II.C.

86 Daley, 487 A.2d at 322.

87 Id. 


\section{Changes to the Immigration Landscape}

In the late 1980s, Congress began to revise the INA as it related to individuals with convictions. The resulting revisions have been profound and have undermined the factual basis for the courts' early decisions on the nature of the immigration consequences of convictions. The revisions began slowly and gathered steam until they culminated in 1996 with the revolution in the law of immigration and convictions that was embodied in the passage of two laws: the Antiterrorism and Effective Death Penalty Act of 1996 (AEDPA), ${ }^{88}$ and the Illegal Immigration Reform and Immigrant Responsibility Act of 1996 (IIRIRA). ${ }^{89}$ These changes vastly expanded the universe of crimes for which an individual could be excluded or deported, eliminated the Attorney General's discretion to waive removal for those convicted of many offenses, allowed criminal sentencing judges to impose deportation or removal directly for any removable individual, and made a number of other significant changes related to the imposition of deportation following the entry of a conviction.

Congress started down this road with the Anti-Drug Abuse Act of $1988^{90}$ when it invented the category of offense called the "aggravated felony," which at that time was defined as murder or trafficking in drugs or weapons. ${ }^{91}$ Those convicted of aggravated felonies were made deportable, were subject to mandatory detention during deportation proceedings, and were disqualified from a form of relief from deportation called "voluntary departure." 92 At that time, Congress also expanded the range of firearms offenses that rendered one deportable. ${ }^{93}$ It did not, however, make any changes to the section 212(c) discretionary relief from deportation, which still provided relief to thousands of noncitizens convicted of crimes.

In 1990, Congress again acted to expand deportability and restrict discretionary relief for those convicted of crimes. It expanded the definition of an "aggravated felony" to include drug trafficking, money laundering, and any crime of violence for which a term of imprisonment of five years or more was imposed; it also barred section 212(c) discretionary relief for anyone convicted of an aggravated felony who was

88 Pub. L. No. 104-132, 110 Stat. 1214 (1996) [hereinafter AEDPA].

89 Pub. L. No. 104-208, 110 Stat. 3009-546 (1996) [hereinafter IIRIRA].

90 Pub. L. No. 100-690, 102 Stat. 4181 (1988) (codified as amended in scattered sections of 19-22 U.S.C., 25 U.S.C., $28-29$ U.S.C., 31 U.S.C., 42 U.S.C., and 50 U.S.C.) [hereinafter Anti-Drug Abuse Act].

91 Id. $\S 7342,102$ Stat. at $4469-70$.

92 Id. $\S \S 7344(\mathrm{a}), 7343(\mathrm{a}), 7343(\mathrm{~b}), 102$ Stat. at 4470-71. Voluntary departure is discretionary relief which allows certain individuals who are out of lawful status to depart the United States by a certain deadline and without a formal order of deportation or removal, thus avoiding the negative consequences of such an order. INA $\S 240 \mathrm{~B}, 8$ U.S.C. $§ 1229 \mathrm{c} \mathrm{(2006).}$

93 Anti-Drug Abuse Act $\S 7342,102$ Stat. at 4469-70. 
sentenced to at least five years of imprisonment. ${ }^{94}$ It also eliminated judicial recommendations against deportation for any conviction. ${ }^{95}$

Significantly, the Immigration Act of 1990 ("IMMACT90") also began a long process of restricting and streamlining procedures for adjudicating cases involving the recently created and already expanding category of aggravated felonies. For example, IMMACT90 section 504 provided for mandatory detention of all aggravated felons except lawful permanent residents pending the outcome of deportation proceedings. 96 IMMACT90 also required states, as a way of facilitating identification and immigration prosecution of those convicted of crimes, to establish a plan to provide the Immigration and Naturalization Service (INS) ${ }^{97}$ with certified records of conviction within thirty days of any conviction under state law. ${ }^{98}$

A few years later, Congress made further efforts to streamline the deportation process for individuals convicted of aggravated felonies in the Violent Crime Control and Law Enforcement Act of 1994.99 For the first time, this Act gave the Attorney General the considerable power to bypass deportation proceedings entirely for any noncitizen who was not a lawful permanent resident, who was convicted of an aggravated felony, and who was ineligible for relief from deportation. ${ }^{100}$ Individuals in this category were deprived of the right to an administrative deportation hearing before an immigration judge and permitted only limited judicial review of the agency decision to determine whether they were, in fact, not lawful permanent residents, not eligible for relief, and had been convicted of an aggravated felony. ${ }^{101}$ At the same time, Congress began a long process of tightening connections between the criminal and immigration systems to ensure that individuals who were deportable for convictions were directly identified and deported. 102

In the same year, through the Immigration and Nationality Technical Corrections Act of 1994, Congress took the radical step of giving federal criminal sentencing judges jurisdiction in certain circumstances to issue an order of deportation based on a criminal conviction at the same time as the sentencing, thereby bypassing entirely a separate deportation process. ${ }^{103}$

94 Immigration Act of 1990 , Pub. L. No. 101-649, § 501, 104 Stat. 4978, 5048 [hereinafter IMMACT90]; id. $\S 511,104$ Stat. at 5052.

95 ld. $\S 505,104$ Stat. at 5050.

96 Id. § 504, 104 Stat. at 5049-50.

97 The INS was the predecessor of the current DHS's United States Citizenship and Immigration Service, Immigration and Customs Enforcement (ICE), and Customs and Border Protection (CBP).

98 IMMACT $90 \S 507,104$ Stat. at 5050-51.

99 Pub. L. No. 103-322, 108 Stat. 1796 (1994) [hereinafter Violent Crime Act].

$100 \quad$ Id. $\S 130,004,108$ Stat. at 2026.

101 Id.

102 See, e.g., id. $\S 130,002,108$ Stat. at 2023.

103 Immigration and Nationality Technical Corrections Act of 1994, Pub. L. No. 103-416, $\S 224,108$ Stat. 4305, 4322-24 (1994). 
Congress also significantly expanded the definition of "aggravated felony" again, so that the definition now included sixteen different offenses ranging from failure to appear to serve a sentence of fifteen years or more to murder, 104 and expanded the grounds for deportation and exclusion for many crimes to include attempts and conspiracies to commit those crimes. 105

Up to this time, Congress had significantly expanded the criminal grounds for deportation and exclusion and had begun to address the problem of identification and enforcement against noncitizens with convictions. However, in 1996, Congress substantially overhauled the way that immigration law had previously treated individuals with convictions when it passed AEDPA and IIRIRA.

These two laws together revolutionized the way that convictions were addressed by the immigration system. ${ }^{106}$ They redefined and substantially broadened (again) the universe of crimes for which one could be removed from the United States by expanding the definition of what constitutes both a conviction and a term of imprisonment for immigration purposes (including, for example, suspended sentences within the latter for the first time).107 They also broadened the definition of aggravated felonies to include, among other things, any crime of theft or violence for which a sentence of only one year was imposed. ${ }^{108}$ The reach of current INA provisions regarding crimes is extremely long. Noncitizens are rendered removable or inadmissible for offenses involving moral turpitude, ${ }^{109}$ virtually any drug offense, ${ }^{110}$ firearms offenses, ${ }^{111}$ domestic violence offenses, 112 and aggravated felonies. 113

The category of aggravated felony is in turn quite broad, and now includes a "stunning range" of offenses, 114 many of which are neither "aggravated" nor felonies. The list currently includes twenty separate categories of charges, and encompasses a wide range of offenses, some of

104 Id. $\$ 222,108$ Stat. at 4320-22.

105 Id. $\S \S 203,222,108$ Stat. at $4311,4322$.

106 IIRIRA even changed the very basic categories of deportation, eliminating "deportation" and "exclusion" proceedings in favor of the single "removal" proceeding. See INA § 240 (a), 8 U.S.C. $§ 1229$ (a) (2006); IIRIRA, div. C, $\S \S 304,309$ (d)(2), 110 Stat. at 3009-587, 3009627.

107 IIRIRA $\S 322(a)(1), 110$ Stat. at 3009-628 to 3009-629.

108 Id. $\S 321(\mathrm{a})(3), 110$ Stat. at 3009-627.

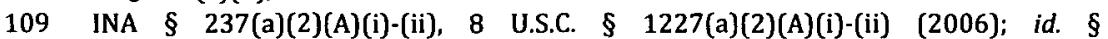
$212(\mathrm{a})(2)(\mathrm{A})(\mathrm{i})(\mathrm{I}), 8$ U.S.C. $\$ 1182(\mathrm{a})(2)(\mathrm{A})(\mathrm{i})(\mathrm{I})$.

110 Id. $\S 237(\mathrm{a})(2)(\mathrm{B}), 8$ U.S.C. $\S 1227(\mathrm{a})(2)(\mathrm{B}) ; i d . \S 212(\mathrm{a})(2)(\mathrm{A})(\mathrm{i})(\mathrm{II}), 8$ U.S.C. $\S$ $1182(\mathrm{a})(2)(\mathrm{A})(\mathrm{i})(\mathrm{II})$.

111 Id. $\S 237(\mathrm{a})(2)(\mathrm{C}), 8$ U.S.C. $\$ 1227(\mathrm{a})(2)(\mathrm{C})$.

112 Id. $\S 237(\mathrm{a})(2)(\mathrm{E}), 8$ U.S.C. $\$ 1227(\mathrm{a})(2)(\mathrm{E})$.

113 Id. $\$ 237(\mathrm{a})(2)(\mathrm{A})(\mathrm{iii}), 8$ U.S.C. $\$ 1227(\mathrm{a})(2)(\mathrm{A})(\mathrm{iii})$.

114 Legomsky, supra note 46 , at 520. 
which are quite serious, but many of which are relatively minor. ${ }^{115}$ Some of the aggravated felony provisions are triggered by sentences of incarceration of one year or more, but the inclusion of suspended sentences within this definition means that even sentences with no actual jail time can trigger the aggravated felony provisions. ${ }^{116}$ As a result, "aggravated felony" offenses now include "simple" assault with a sentence or suspended sentence of a year or more, ${ }^{117}$ possession of marijuana with intent to distribute (regardless of sentence), 118 and even petty theft with a prior jail term, where a sentence or suspended sentence of a year or more is imposed. ${ }^{119}$ Congress further defined aggravated felony to include any attempt or conspiracy to commit any of these crimes ${ }^{120}$ as well as any such conviction entered at any time, whether "before, on, or after the date of enactment" of the new definition, meaning that offenses that were not aggravated felonies or deportable offenses when they were committed have become so. ${ }^{121}$ Finally, AEDPA provided that any individual convicted of an aggravated felony "shall be conclusively presumed to be deportable from the United States." 122

Even more significantly, IIRIRA eliminated the immigration judge's traditional power to exercise discretion on behalf of any individual with a conviction that fell within the much-expanded aggravated felony definition. IIRIRA eliminated the traditional section 212 (c) waiver ${ }^{123}$ and-among other restrictions-replaced it with a much more limited form of relief for which individuals with aggravated felony convictions were made categorically ineligible. ${ }^{124}$ The section 212(c) waiver, which had provided discretionary relief from removal for many thousands of individuals annually prior to 1996 , was no longer. 125

Furthermore, AEDPA and IIRIRA included a variety of provisions that significantly tightened the coordination between criminal and immigration proceedings, to ensure that criminal defendants passed as directly as possible from the state or federal criminal systems to removal proceedings. For example, the Attorney General was directed to detain all individuals convicted of virtually any crime upon their release from

\footnotetext{
115 INA § 101(a)(43)(A)-(U), 8 U.S.C. $\$ 1101(\mathrm{a})(43)(A) \cdot(\mathrm{U})(2006)$.

$116 \quad$ Id. $\S 101(\mathrm{a})(48)(\mathrm{B}), 8$ U.S.C. $\$ 1101(\mathrm{a})(48)(\mathrm{B})$.

117 See, e.g., United States v. Cordoza-Estrada, 385 F.3d 56, 57 (1st Cir. 2004) (holding that simple assault for punching a man in the face is an aggravated felony).

118 Julce v. Mukasey, 530 F.3d 30, 32 (1st Cir. 2008) (holding that possession of marijuana with intent to distribute is an aggravated felony).

119 Mutascu v. Gonzales, 444 F.3d 710, 711 (5th Cir. 2006).

120 INA $\S 101(\mathrm{a})(43)(U), 8$ U.S.C. $\$ 1101$ (a)(43)(U) (2006).

121 Id.

122 AEDPA $\S 442(\mathrm{c}), 110$ Stat. at 1280.

123 IIRIRA § 304(b), 110 Stat. at 3009-597.

124 Id. § 304(a), 110 Stat. at 3009-587 to 3009-597; see also INA § 240a(a)(3), 8 U.S.C. § $1229 \mathrm{~b}(\mathrm{a})(3)(2006)$.

125 Immigration \& Naturalization Serv. v. St. Cyr, 533 U.S. 289, 296 (2001).
} 
incarceration, parole, supervised release, or probation, and was directed to hold them, with no possibility of release on bond, pending removal proceedings and after an order of removal. ${ }^{126}$ Thus, after this provision went into effect in 1998, any removable individual incarcerated even for a short time was subject to mandatory detention until the government could complete removal proceedings and effectuate removal. AEDPA also broadened provisions for holding expedited removal proceedings for convicted individuals while they are still serving their criminal sentences. ${ }^{127}$ IIRIRA expanded the jurisdiction of federal district court judges to enter removal orders at the time of criminal sentencing. Where earlier law had given them jurisdiction to order removal only in cases involving aggravated felony convictions, IIRIRA gave a district court sentencing judge the power to order the removal of any alien "who is deportable." 128 It also wrote into statute the authority of sentencing judges to enter a removal order as a condition of probation. ${ }^{129}$ Finally, Congress ordered immigration authorities to continue to develop systems to identify and track noncitizens with convictions, including a criminal alien identification system that would be used to help local, state, and federal law enforcement identify and locate noncitizens subject to removal because of convictions. ${ }^{130}$

\section{The Directness of Immigration Consequences in the Current Legal Framework}

The calculus for all of the factors considered by earlier courts in analyzing the directness of immigration consequences-definiteness, immediacy, the automatic nature of the sanction, and the independence of the decision-maker-has been changed by the revolution in immigration law and enforcement that has occurred gradually over the course of the last two decades. An analysis of the current landscape of immigration law and enforcement relating to convictions reveals that removal does, in fact, function as punishment, and, at least in the case of those convicted of aggravated felonies, has come to a point where it can very fairly be characterized as the definite, immediate, and automatic consequence of the criminal court's action.

\footnotetext{
126 IIRIRA § 303(a), 110 Stat. at 3009-585 to 3009-587.

127 AEDPA $\S 442,110$ Stat. at 1279-80.

128 IIRIRA $\S 374,110$ Stat. at $3009-647$ to $3009-648$; INA $\S 238(c)(1), 8$ U.S.C. $\S$ $1228(\mathrm{c})(1)(2006)$.

129 IIRIRA $\S 374,110$ Stat. at 3009-647 to 3009-648.

130 Violent Crime Act $\S 130,002,108$ Stat. at 2023, amended by AEDPA, tit. IV, $\S 432,110$ Stat. at 1273; IIRIRA, div. C, tit. III, $\S \S 308(\mathrm{~g})(5)(B), 326,327,110$ Stat. at 3009-623, 3009-630.
} 


\section{A. Removal as a Punitive Sanction}

As we have seen, courts have consistently held that deportation is a remedial rather than punitive sanction. Earlier courts addressing the directness of the deportation consequences of conviction concluded that deportation was "neither 'definite' nor 'largely automatic,"'131 and that it was the result of the independent action of a government agency that was, in turn, independent of the criminal court. As such, these courts held deportation to be a collateral consequence of conviction. ${ }^{132}$ The Daley court, for example, relied specifically on the availability of discretionary relief in separate, substantive immigration proceedings, as well as the uncertainties of enforcement. ${ }^{133}$ Indeed, in that time period, the eventual outcome of deportation was contingent on the happenstance of whether the individual came to the attention of the immigration authorities, who had few systems to identify him, and whether they instituted proceedings against him, as well as whether the individual qualified by his circumstances for a section 212(c) waiver or other discretionary relief from deportation.

However, if we vigorously analyze the nature of the removal sanction and apply the "definite, immediate and largely automatic effect" 134 standard used by earlier courts to immigration consequences as they operate today, the conclusion is very different. We find that removal in fact functions as punishment and that immigration law and its enforcement infrastructure have changed to such an extent in the past two decades that removal has become a direct consequence of many convictions for noncitizens. This is particularly true for anyone convicted of any of the myriad offenses now classified as aggravated felonies by the immigration law.

Courts continue to state without argument that removal universally serves a remedial purpose and is imposed to remedy an ongoing violation of the immigration law. ${ }^{135}$ This characterization of the sanction certainly applies in the case of some immigration violations. For example, a student visa is issued on the condition that the student be enrolled full-time in school. ${ }^{136}$ When an individual with such a visa fails to enroll in school (or to enroll full-time), she has violated the terms of her admission and continues to violate those terms as long as she remains in the country on

131 Daley v. State, 487 A.2d 320, 322 (Md. Ct. Spec. App. 1985).

132 See United States v. Littlejohn, 224 F.3d 960, 965 (9th Cir. 2000); United States v. Lambros, 544 F.2d 962, 966 (8th Cir. 1976); Fruchtman v. Kenton, 531 F.2d 946, 949 (9th Cir. 1976); Daley, 487 A.2d at 322.

133 Daley, 487 A.2d at 322.

134 Cuthrell v. Director, 475 F.2d 1364, 1366 (4th Cir. 1973).

135 See, e.g., Reno v. Am.- Arab Anti-Discrimination Comm., 525 U.S. 471, 491 (1999).

1368 U.S.C. $\$ 1101(a)(15)(F)$ (2006). 
her student visa without being enrolled in school. The same can be said for an individual who is admitted to the country in order to work for a particular employer and fails to do so. In a slightly different way, the same can also be said for one who enters without inspection, because (though there has been no legal entry) the violation is likewise ongoing. In these contexts, it makes sense to say that removal remediates an ongoing violation of the immigration law.

The same reasoning does not apply to an individual who is legally authorized to be in the country and whose removability arises solely from the fact that she has been convicted of a criminal offense. In that case, the ground of removability has no relation to the conditions of admission; the criminal grounds of removal apply regardless of the type of visa or conditions on the individual's admission. Indeed, a number of the criminal grounds of removal have no analogue in the provisions that govern admission. For example, certain firearm offenses are grounds for removability but not inadmissibility. ${ }^{137}$ In fact, while many aggravated felonies also fall within independent grounds of inadmissibility, the aggravated felony ground of removal itself 138 has no counterpart in the standards for admission.

Likewise, the finding of the violation in no way depends on any ongoing conduct, threat, or requirement, but is satisfied by evidence of the past act alone. The "remedial" nature of the sanction, according to the case law, lies simply in the removal from the community of one who has committed the past act. There is no claim that removal accomplishes any other remedial purpose nor that there is any ongoing requirement or condition that is being violated. Thus, in the context of removal for a criminal conviction, despite the applied rhetoric of ongoing violations and remedial sanctions, deportability is based on and justified by the past act alone. As such, it functions as punishment for that act rather than as a remedy for any ongoing violation of the immigration law.

\section{B. Removal as an Automatic Sanction for Aggravated Felony Convictions}

As we have seen, changes in the immigration statutes have made removal quite "definite, immediate and largely automatic" for any individual convicted of an aggravated felony. The immigration consequences of an aggravated felony conviction are categorical, arising directly from the fact of the conviction, regardless of the severity of the actual offense. The law states plainly that any "alien convicted of an aggravated felony shall be conclusively presumed to be deportable from

137 INA $\S 237(\mathrm{a})(2)(\mathrm{C}), 8$ U.S.C. $\$ 1227(\mathrm{a})(2)(\mathrm{C})$.

138 ld. $\S 237(\mathrm{a})(2)(\mathrm{A})(\mathrm{iii}), 8$ U.S.C. $\$ 1227(\mathrm{a})(2)(\mathrm{A})(\mathrm{iii})$. 
the United States." 139 Furthermore, noncitizens convicted of aggravated felonies are automatically and mandatorily disqualified from virtually any discretionary relief from removal, including cancellation of removal for lawful permanent residents, the form of relief that replaced the much utilized section $212(\mathrm{c})$ waiver. ${ }^{140}$ The fact of the conviction itself strips an immigration judge of any power to grant relief from removal. Following removal for an aggravated felony conviction, an individual is permanently barred from reentering the United States. ${ }^{141}$

As a result of the conclusive presumptions and disqualifications written into the law, removal has become automatic for anyone with a conviction falling within the category of aggravated felonies. Immigration judges are powerless to do anything other than confirm the fact of the conviction and order removal. In the 2002 case of United States v. Couto, 142 the Second Circuit put it thus:

Given [the 1996 immigration law] amendments, an alien convicted of an aggravated felony is automatically subject to removal and no one-not the judge, the INS, nor even the United States Attorney General-has any discretion to stop the deportation. Therefore, Defendant argues, the rationale behind the decisions in Parrino and Santelises - that deportation is not a direct consequence because it is not automatic-no longer reflects the state of the law. Instead, deportation today is an essentially certain, automatic, and unavoidable consequence of an alien's conviction for an aggravated felony. ${ }^{143}$

Five years later, in Zhang v. United States, ${ }^{144}$ the same court went on to say even more directly:

139 Id. $\S 238(\mathrm{c}), 8$ U.S.C. $\S 1228(\mathrm{c})$. More generally, the law provides that any "alien convicted of an aggravated felony at any time after admission is deportable." Id. $\S$ $237(\mathrm{a})(2)(\mathrm{A})(\mathrm{iii}), 8$ U.S.C. $\$ 1227(\mathrm{a})(2)(\mathrm{A})(\mathrm{iii})$.

140 Id. $\S 240 \mathrm{~A}(\mathrm{a})(3), 8$ U.S.C. $\S 1229 \mathrm{~b}(\mathrm{a})(3)$. In addition, individuals with these convictions are specifically barred from seeking cancellation of removal for individuals who are not legal permanent residents, special cancellation of removal for Central Americans under the Nicaraguan Adjustment and Central American Relief Act, voluntary departure, relief under the battered spouse provisions of the Violence Against Women Act, naturalization, and, in most cases, temporary protected status. See id. $\S 101(\mathrm{f})(8), 8$ U.S.C. $\S 1101(\mathrm{f}(8) ;$ id. $\S 240 A(\mathrm{~b})(1)(B), 8$ U.S.C. $\S$ $1229 \mathrm{~b}(\mathrm{~b})(1)(\mathrm{B}) ;$ id. $\S 240 \mathrm{~A}(\mathrm{~b})(1)(\mathrm{C}), 8$ U.S.C. $\S 1229 \mathrm{~b}(\mathrm{~b})(1)(\mathrm{C}) ;$ id. $\S 240 \mathrm{~B}(\mathrm{a})(1), 8$ U.S.C. $\S$ $1229 \mathrm{c}(\mathrm{a})(1) ;$ id. $\S 240 \mathrm{~B}(\mathrm{~b})(1)(\mathrm{C}), 8$ U.S.C. $\S 1229 \mathrm{c}(\mathrm{b})(1)(\mathrm{C}) ;$ id. $\S 240 \mathrm{~A}(\mathrm{~b})(1)(\mathrm{B}), 8$ U.S.C. $\S$ 1229c(b)(1)(B); id. $\S 240 A(b)(1)(C), 8$ U.S.C. $\$ 1229 b(b)(1)(C) ; 8$ C.F.R. $\$ 1240.65$ (a) (2009); 8 C.F.R. $\S 1244.4$. They are even barred from humanitarian relief from persecution in the form of asylum and, in many circumstances, the more limited withholding of removal, as well. See INA $\S$ $208(\mathrm{~b})(2)(\mathrm{B})(\mathrm{i}), 8$ U.S.C. $\S 1158(\mathrm{~b})(2)(\mathrm{B})(\mathrm{i})(2006) ; \quad$ id. $\$ 208(\mathrm{~b})(2)(\mathrm{A})(\mathrm{ii}), 8$ U.S.C. $\S$ 1158(b)(2)(A)(ii); id. $\S 241(\mathrm{~b})(3)(\mathrm{C}), 8$ U.S.C. $\S 1231(\mathrm{~b})(3)(\mathrm{C}) ;$ id. $\S 241(\mathrm{~b})(3)(\mathrm{B})(\mathrm{ii}), 8$ U.S.C. $\S$ 1231(b)(3)(B)(ii).

141 ld. $\$ 212(\mathrm{a})(9)(\mathrm{A})(\mathrm{i}), 8$ U.S.C. $\$ 1182(\mathrm{a})(9)(\mathrm{A})(\mathrm{i})$.

142311 F.3d 179 (2d Cir. 2002).

143 Id. at 189-90.

144506 F.3d 162 (2d Cir. 2007). 
The passage of the Illegal Immigration Reform and Immigrant Responsibility Act of 1996 ("IIRIRA") and the Antiterrorism and Effective Death Penalty Act of 1996 ("AEDPA"), however, has altered the landscape of immigration law, and deportation of aggravated felons is now automatic and non-discretionary. [S]ee also INS v. St. Cyr (referring to deportation of aggravated felons as "certain"). ${ }^{145}$

The court in both cases found that it did not have to decide the issue of directness, 146 but observed in dictum that it found merit in the argument that the consequence of deportation was now automatic for individuals with aggravated felony convictions. ${ }^{147}$

\section{Removal as a Definite and Immediate Sanction}

On the mandate of and with considerable support from Congress, immigration and criminal authorities have collaborated on systems that have made removal both definite and immediate. Removal now generally follows right on the heels of the criminal process and sentence, often even before the sentence has been served. Earlier courts found that removal was neither definite nor immediate following a conviction, observing the dumb luck that seemed to determine whether an individual with a conviction would come to the attention of the authorities or not and the long delays between conviction and deportation, when it did occur. ${ }^{148}$ In contrast, significant systems now ensure that noncitizen criminal defendants are identified quickly and move directly and immediately to immigration proceedings or even straight to removal, and DHS has prioritized the removal of noncitizens with convictions. ${ }^{149}$ DHS is required by law to take custody of an individual with a removable conviction directly upon his or her release from state or local custody, and the

145 Id. at 167 (first citation omitted).

146 In Couto, the court held that the defendant was entitled to withdraw her plea because she was misled by her counsel. 311 F.3d at 188 . In Zhang, the court found that the defendant was, in fact, advised by the court of possible immigration consequences of his plea and remanded for further proceedings on the question of ineffective assistance of counsel. 506 F.3d at 169.

147 Zhang, 506 F.3d at 167; Couto, 311 F.3d at 189-90.

148 See Daley v. State, 487 A.2d 320, 322 (Md. Ct. Spec. App. 1985). The Daley court observed that deportation proceedings in that case were not necessarily "immediate," as the defendant in Daley only came to the attention of the immigration authorities and was put into deportation proceedings nearly two years after he pled guilty, when he happened to reenter the country after travel abroad. Id. The court observed that proceedings "might never have been instituted" had he not left the country. Id.

149 See, e.g., Oversight of the Department of Homeland Security: Hearing Before the S. Comm. on the Judiciary, 111th Cong. (2009) (statement of Janet Napolitano, Sec'y of Homeland Sec.), available at http://judiciary.senate.gov/hearings/testimony.cfm?renderforprint $=1 \& i d=3803$ \&wit_id=7873 ("These new [enforcement] protocols reflect a renewed Department-wide focus on two different emphases for our immigration enforcement efforts: first, targeting criminal aliens, and second targeting employers who cultivate illegal workplaces ...."). 
government has sophisticated systems in place to identify and keep track of these individuals even while they are still serving their criminal sentences. 150

Beginning with the reforms of the 1990s, immigration authorities have been required to implement and maintain extensive systems to tighten the connections between the formerly separate criminal and immigration enforcement infrastructures. ${ }^{151}$ Congress has generously funded these mandates. ${ }^{152}$ As a result, through a number of programs designed to address different aspects of this interaction, the Department of Homeland Security now has established a "Comprehensive Plan to Identify and Remove Criminal Aliens." 153 The goal of this web of enforcement programs is to ensure that all individuals in any stage of the criminal process-from the moment of a law enforcement stop through the sentencing of a convicted individual and even beyond the completion of a sentence-are screened for removability and, if appropriate, surrendered into U.S. Immigration and Customs Enforcement (ICE) custody. ${ }^{154}$ The development of these systems for identifying and processing "criminal aliens" has been and continues to be among the highest priorities for ICE. 155

This "Secure Communities" initiative, which ICE unveiled in 2008, identifies and draws together many of the components of the comprehensive system that immigration authorities have developed over the years, in conjunction with federal, state, and local law enforcement and others, to identify and process noncitizens with convictions. The plan is the culmination of several years of serious investment by ICE in an infrastructure that is "transforming the way the federal government cooperates with state and local law enforcement agencies to identify,

$150 \quad$ Id.

151 For one example, under INA section 236(d), DHS is required to implement and maintain a computer-based system to identify aliens in state and local custody who have been arrested for aggravated felonies and to facilitate communication with federal authorities regarding the arrest, conviction, and release of such individuals. INA $\S 236$ (d), 8 U.S.C. $\S 1226$ (d) (2006).

152 It does not appear that support for these programs will diminish anytime soon. The federal budget recently proposed by the Obama Administration would include $\$ 1.4$ billion designated specifically for ICE programs to deport noncitizens who commit crimes. How the \$3.6 Trillion Would Be Spent, WASH. POST, Feb. 27, 2009, at A7.

153 See U.S. Immigration \& Customs Enforcement, Secure Communities (Nov. 19, 2008) (on file with The Yale Journal on Regulation) [hereinafter ICE Fact Sheet].

154 Id.

155 U.S. IMMIGRATION \& CUSTOMS ENFORCEMENT, ICE FISCAL YEAR 2007 ANNUAL REPORT: Protecting National Security and Upholding Public SafeTy 4-5 (2008), available at http://www.ice.gov/doclib/about/ice07ar_final.pdf [hereinafter ICE FISCAL YEAR 2007 ANNUAL REPORT] ("At the same time, ICE has introduced an aggressive and effective campaign to enforce immigration law within the nation's interior, with a top-level focus on criminal aliens .... Aliens involved in criminal activity are a threat to the safety and security of the American public and were a key focus for ICE in FY07."). 
detain and remove all criminal aliens held in custody." 156 ICE has coordinated enforcement efforts among myriad agencies at all levels of government in this effort. In addition to state and local law enforcement agencies, 157 its federal partners in this effort include U.S. Citizenship and Immigration Services (USCIS), Customs and Border Protection (CBP), and the United States Visitor and Immigrant Status Indicator Technology (USVISIT) Program within DHS, as well as agencies beyond DHS: the Bureau of Prisons (BOP), the Executive Office for Immigration Review, U.S. Attorneys, the Department of State (DOS), the Department of Justice, the U.S. Marshals Service, and the FBI's Criminal Justice Information Services Division. ${ }^{158}$

In June 2007, ICE consolidated its efforts and resources into its Criminal Alien Program (CAP), charged with identifying, detaining, and removing noncitizens with convictions. ${ }^{159}$ CAP uses a variety of programs to screen inmates in federal, state, and local prisons and jails throughout the country, to place DHS detainers on them to ensure that they pass directly to DHS custody, and to secure removal orders against them before they can be released from the custody of the criminal system. In fiscal year 2008, CAP officers issued charging documents to begin removal proceedings against more than 221,000 noncitizens with convictions. This was a significant increase from 164,000 in fiscal year 2007 and 67,000 in fiscal year 2006. 160

The Detention Enforcement and Processing Offenders by Remote Technology (DEPORT) Center in Chicago uses video teleconference equipment to interview federal BOP inmates for immigration screening and to begin proceedings. As a result of the DEPORT Center and local ICE efforts, inmates from all 114 federal detention centers are now screened and taken directly into ICE custody, if appropriate, upon completion of their sentences. ${ }^{161}$ Together, CAP and DEPORT officers also currently screen all foreign-born individuals in all state prisons. ${ }^{162}$

In addition, from the time any state, local, or federal law enforcement officer stops an individual, that officer has access to ICE's Law Enforcement Support Center (LESC), a national enforcement operations facility that provides the officer with real-time immigration status and identity information twenty-four hours a day, seven days a week, even when the

156 ICE Fact Sheet, supra note 153.

157 For a window into the growing cooperative relationship between ICE and New York, see N.Y. Div. of Criminal Justice ServS., Criminal Alien ImprovementS in NeW York State: 2006 CRIMESTAT UPDATE (2007), available at http://criminaljustice.state.ny.us/pio/annualreport/criminalalienimprovements.pdf.

158 See ICE Fact Sheet, supra note 153.

159 ld.

160 Id.

161 ICE FISCAL YEAR 2007 ANNUAL REPORT, supra note 155; ICE Fact Sheet, supra note 153.

162 ICE Fact Sheet, supra note 153. 
individual has not been arrested. ${ }^{163}$ Prior immigration and criminal history data are available even if the individual is merely subject to a traffic or other stop and is accessible by any law enforcement officer in any case, including in the case of individuals charged and held in local jails. In fiscal year 2008, LESC responded to 807,106 requests for information from other law enforcement agencies which came from 12,000 different sources including agencies in all fifty states and the District of Columbia. ${ }^{164}$ Over the past five fiscal years, LESC agents lodged 79,450 immigration detainers against individuals with convictions or prior immigration violations. 165

In addition, LESC administers the 250,000 ICE records in the National Crime Information Center database, which gives local law enforcement officers direct access to immigration-related records. ${ }^{166}$ ICE is also working on establishing interoperability between the FBI's Integrated Automated Fingerprint Identification System and DHS's Automated Biometric Identification System, which will facilitate the positive identification of individuals in local prisons and jails. 167

As soon as foreign-born individuals with convictions are identified in the criminal system, DHS places a detainer on them to ensure that they are surrendered directly into DHS custody. If the individual has not earlier had a removal hearing, proceedings to remove him or her are begun in most cases after the individual goes into DHS custody on the detainer. ${ }^{168}$

Furthermore, individuals with virtually any criminal conviction are subject to mandatory detention during the pendency of their removal proceedings, ${ }^{169}$ and federal law requires that the DHS ${ }^{170}$ "shall" take them into custody immediately upon their release from state custody, including release on parole, supervised release, or probation. ${ }^{171}$ This ensures that these individuals are unable to abscond or to avoid being subjected to any immigration process that might flow from their convictions.

163 U.S. Immigration \& Customs Enforcement, Law Enforcement Support Center (Nov. 19, 2008), http://www.ice.gov/pi/news/factsheets/lesc.htm.

164 ld.

165 Id.

166 Id.

167 Id.

168 Telephone Interviews and E-mail Correspondence with Joanna Silver, Fed. Pub. Defender, Dist. of Md. (Jan. 9, 2009); Laura Kelsey Rhodes, Private Criminal Def. Attorney (Jan. 9, 2009); Deirdre Mokos, Fed. Pub. Defender, Dist. of Ariz., Tucson Div. (Jan. 8, 2009) (any opinion stated by Ms. Mokos is hers only and not that of the Federal Public Defender of Arizona); Laura Harper, Fed. Pub. Defender, N. Dist. of Tex., Dallas Div. (Jan. 7, 2009); Frank Mangan, Fed. Pub. Defender, S. Dist. of Cal., San Diego Div. (Jan. 6, 2009) (on file with The Yale Journal on Regulation).

169 INA $\S 236(c), 8$ U.S.C. $\S 1226(c)$ (2006) (providing for mandatory detention of anyone removable or inadmissible for convictions of crimes involving moral turpitude, aggravated felonies, drug offenses, firearms, and "miscellaneous" offenses).

170 With the transfer of authority under 6 U.S.C. $\S 557$ as of March 1, 2003, the title "Attorney General" refers to the Secretary of Homeland Security with respect to certain federal law. United States v. Rios-Zamora, 153 F. App'x 517, 520-21 (10th Cir. 2005).

171 INA $\S 236(c), 8$ U.S.C. $§ 1226(c)(2006)$. 
In many cases, immigration removal proceedings are begun and even completed before an individual leaves state or federal custody. Current law provides for removal proceedings to be held in correctional facilities for those with aggravated felony convictions, in an effort to ensure that proceedings are completed while the individual is still serving his or her sentence for the criminal charge and that removal can occur directly upon the individual's release to DHS custody. ${ }^{172}$ These proceedings take place through the ICE Institutional Removal Program (IRP), which is the vehicle for this overlap between criminal and immigration enforcement. The number of individuals receiving an order of removal while serving a criminal sentence has increased markedly in recent years. ${ }^{173}$

Even beyond the IRP, though, there is the so-called "administrative" removal process for individuals with aggravated felony convictions who are not lawful permanent residents. ${ }^{174}$ The INA provides that any such individual may be ordered removed by a DHS employee in a summary and strictly administrative process without any hearing or removal proceeding at all. 175 This streamlined "process" is reduced to a ministerial function by two other sections of the statute that provide that any individual with an aggravated felony conviction is "conclusively presumed" deportable on the basis of the conviction alone ${ }^{176}$ and, again on the basis of the conviction alone, specifically made ineligible for any discretionary forms of relief. ${ }^{177}$ Thus, the role of the decision-maker in these cases, a DHS employee, is merely to confirm the identity of the individual and the existence of the conviction. From the fact of that conviction, the law mandates that the individual is deportable and has no discretionary relief and therefore must be ordered removed. Though DHS refers to these orders as

172 Id. $\S 238(\mathrm{a}), 8$ U.S.C. $\S 1228(\mathrm{a})$.

173 BOP employee Kathy Grinley is quoted in the ICE Fiscal Year 2007 Annual Report as saying, "During the past year, there has been a noticeable increase in the number of inmates in BOP custody who have received an order of removal while serving their sentence." ICE FISCAL YEAR 2007 ANNUAL REPORT, supra note 155 , at 6.

174 See INA $\S 238(b), 8$ U.S.C. $\S 1228(b)$ (2006). It is also noteworthy that this provision can be applied to the conditional permanent resident spouse of a U.S. citizen, that is, an individual granted adjustment of status to permanent residence within two years of marriage to a citizen. $I d$. $\S 238(\mathrm{~b})(2)(B), 8$ U.S.C. $\S 1228(\mathrm{~b})(2)(B)$. Such an individual has the same rights as a lawful permanent resident to reside, work and reenter the United States, but must apply to remove the condition on her residence after two additional years of marriage. Id. $\S 216,8$ U.S.C. $\S 1186(a)$. Though conditional permanent residents are considered the equivalent of lawful permanent residents for many purposes, the Board of Immigration Appeals has held that they can be subjected to summary administrative removal just like undocumented individuals. See, e.g., In re Spitzauer, No. A73-446-031, 2004 WL 1739208 (B.I.A. July 16, 2004).

175 See INA § 238(b), 8 U.S.C. § 1228(b) (2006).

$176 I$ Id. $\S 238($ c), 8 U.S.C. $\$ 1228$ (c) ("Presumption of deportability. An alien convicted of an aggravated felony shall be conclusively presumed to be deportable from the United States.").

177 Id. $\S 238(\mathrm{~b})(5), 8$ U.S.C. $\S 1228(\mathrm{~b})(5)$ ("No alien described in this section shall be eligible for any relief from removal that the Attorney General may grant in the Attorney General's discretion."). 
"administrative" orders of removal, 178 one commentator has suggested that they are more accurately called "ministerial" orders because the order is entered following the unilateral exercise of a purely ministerial function on the part of the DHS employee. ${ }^{179}$ In fiscal year 2007, 4242 individuals were administratively ordered removed for criminal convictions without a hearing. ${ }^{180}$ The number of these ministerial or administrative orders of removal entered by DHS employees has risen over the years and rose sharply in fiscal year 2008 to $6514 .{ }^{181}$

Finally, criminal courts themselves are now facilitating the initiation of removal proceedings and, in some cases, actually entering removal orders directly. It is now "routine" in many federal districts, especially those with high foreign-born populations, for judges to order surrender to immigration officials as a condition of supervised release or at the end of any period of incarceration. 182 In cases involving plea bargains, prosecutors often require defendants to stipulate to removal or reinstatement of removal in order to benefit from a "fast track" plea or otherwise strike a deal for the quickest processing and the shortest incarceration. ${ }^{183}$ In many districts, defendants are "routinely" required to waive their right to contest removal proceedings as part of a plea agreement. ${ }^{184}$ One such agreement contained the following provisions:

178 See ICE FISCAL YEAR 2007 ANNUAL REPORT, supra note 155, at 33.

179 Lenni B. Benson, Back to the Future: Congress Attacks the Right to Judicial Review of Immigration Proceedings, 29 CoNN. L. REv. 1411, 1446 n.167 (1997), cited in Margaret H. Taylor \& Ronald F. Wright, The Sentencing Judge as Immigration Judge, 51 EMORY L.J. 1131, 1157 n.103 (2002); see also United States v. Couto, 311 F.3d 179, 190 n.10 (2d Cir. 2002).

180 See ICE FISCAL YEAR 2007 ANNUAL REPORT, supra note 155, at 33.

181 U.S. IMMIGRATION \& CUSTOMS ENFORCEMENT, ICE FISCAL YEAR 2008 ANNUAL REPORT: Protecting National Security and Upholding Public SAFETY 28 (2009), available at http://www.ice.gov/doclib/pi/reports/ice_annual_report/pdf/ice08ar_final.pdf [hereinafter ICE FISCAL YEAR 2008 ANNUAL REPORT].

182 Telephone Interviews and E-mail Correspondence with Joanna Silver, Fed. Pub. Defender, Dist. of Md. (Jan. 8, 2009); Laura Harper, Fed. Pub. Defender, N. Dist. of Tex., Dallas Div. Uan. 7, 2009) (on file with The Yale Journal on Regulation); see United States v. Osbaldo LopezBecerra, No. 08-CR-1309-LRR, 2008 WL 2557455 (N.D. lowa Oct. 9, 2008).

183 Telephone Interviews and E-mail Correspondence with Joanna Silver, Fed. Pub. Defender, Dist. of Md. (Jan. 9, 2009); Deirdre Mokos, Fed. Pub. Defender, Dist. of Ariz., Tucson Div. (Jan. 8, 2009); Frank Mangan, Fed. Pub. Defender S. Dist. of Cal., San Diego Div. (Jan. 6, 2009) (on file with The Yale Journal on Regulation). The vast majority of criminal cases are disposed of through plea agreements. In $2004,57 \%$ of federal felony charges and $95 \%$ of state felony charges were disposed of by means of a negotiated plea agreement. BUREAU OF JUSTICE STATISTICS, U.S. DEP'T OF JUSTICE, FELONY DEFENDANTS IN LARGE URBAN COUNTIES, 2004 - STATISTICAL TABLES tbl.19 (2008), available at http://www.ojp.usdoj.gov/bjs/pub/html/fdluc/2004/tables/fdluc04st19.htm;

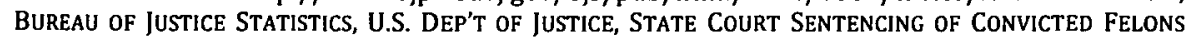
2004 STATISTICAL TABLES tbl.4.1 (2007), available at http://www.ojp.usdoj.gov/bjs/pub/html/scscf04/tables/scs04401tab.htm.

184 E-mail Correspondence with Andre Davis, Fed. Dist. Court Judge, Dist. of Md. Uan. 8, 2009) (on file with The Yale Journal on Regulation); Telephone Interviews and E-mail Correspondence with Laura Harper, Fed. Pub. Defender, N. Dist. of Tex., Dallas Div. (Jan. 8, 2009); (on file with The Yale Journal on Regulation). 
Consent to Removal from the United States

11. The Defendant acknowledges that he is subject to removal from the United States and agrees not to contest any removal proceedings brought by the Department of Homeland Security (DHS).... [T] he Defendant agrees to request an expedited removal hearing and to consent to removal.... The Defendant knowingly waives any and all rights to appeal, reopen, reconsider or otherwise challenge his removal.

12. The Defendant agrees to waive any rights he may have to apply for any form of relief or protection from removal....

14. The Defendant agrees to assist the DHS in his removal. ${ }^{185}$

The plea agreement in these cases acts as a binding contract between the defendant and the U.S. Attorney's Office and prevents the defendant from fighting removal in immigration court. 186

In any event, even when a plea agreement does not directly address immigration status, whenever it comes to the attention of the court or prosecution that a defendant is a noncitizen, it is the practice of the U.S. Attorney's Office to notify ICE so that agents can screen and put a detainer on the individual if ICE believes him or her to be removable. ${ }^{187}$ Individuals with detainers are then transferred directly into the custody of immigration officials at the end of their sentence or criminal process. The system, especially in federal district courts, has become extremely efficient at identifying and detaining removable defendants. One federal defender in Tucson, Arizona estimated that in eight years of working as a federal public defender, she has seen exactly one of her noncitizen former clients mistakenly released following his sentencing; to her knowledge all the rest had detainers by the time they came to her for representation and were surrendered directly to immigration authorities afterwards. ${ }^{188}$

The law allows for even more direct involvement of a federal criminal district court in the process of imposing removal as a result of a criminal conviction. Since the mid-1990s, the INA has provided that a federal district court judge can enter a judicial order of removal directly against any individual convicted of any deportable criminal offense in the course of the criminal proceeding itself. ${ }^{189}$ There is no provision in these cases for any separate DHS administrative or hearing process whatsoever. If the

185 E-mail Correspondence with Andre Davis, Fed. Dist. Court Judge, Dist. of Md. (Jan. 8, 2009) (on file with The Yale Journal on Regulation).

186 E-mail Correspondence with Frank Mangan, Fed. Pub. Defender, S. Dist. of Cal., San Diego Div. (Jan. 6, 2009) (on file with The Yale Journal on Regulation).

187 Telephone Interviews with Joanna Silver, Fed. Pub. Defender, Dist. of Md. Uan. 9, 2009); Laura Kelsey Rhodes, Private Criminal Def. Attorney (Jan. 9, 2009); Laura Harper, Fed. Pub. Defender, N. Dist. of Tex., Dallas Div. (Jan. 7, 2009); Frank Mangan, Fed. Pub. Defender, S. Dist. of Cal., San Diego Div. (Jan. 6, 2009) (on file with The Yale Journal on Regulation).

188 Telephone Interview with Deirdre Mokos, Fed. Pub. Defender, Dist. of Ariz., Tucson Div. (Jan. 8, 2009) (on file with The Yale Journal on Regulation).

189 INA $\S 238(c)(1), 8$ U.S.C. § 1228(c)(1) (2006). 
conviction is the result of a plea rather than a trial, the sentencing judge may enter a stipulated order of removal negotiated as part of a plea agreement. ${ }^{190}$ Additionally, a district court or magistrate judge has statutory authority to order removal as a condition of probation. ${ }^{191}$ In all of these cases, the district court itself enters an order of removal directly at the time of sentencing for the underlying criminal offense, and the individual is transferred without further proceedings to DHS for removal upon completion of any sentence for the criminal charge.

This power of judicial removal was used in the rather notorious proceedings that followed the ICE raid of the Agriprocessors, Inc. meatpacking plant in Postville, Iowa in May 2008. Over the course of ten days in Postville, nearly three hundred workers from the plant were arrested, pled guilty, were convicted of document fraud charges, and were sentenced. 192 Following the entry of sentence in each case, the court issued a stipulated order requiring the removal of the defendant from the United States. ${ }^{193}$ The final order of removal was entered directly by the criminal sentencing judge, and no further proceedings were required or conducted by any immigration authorities.

\section{Removal as a Sanction Imposed Without Independent Due Process}

Finally, a key factor-seemingly in many cases the key factor-for many courts addressing the directness question is that the deportation decision has been made in the context of a separate, civil proceeding and not within the criminal trial. The centrality of this factor can be seen in many of the older cases. ${ }^{194}$

It is striking, however, how this one factor has come to dominate the analysis of courts that have considered the question of the directness of removal following the 1996 changes to the immigration laws. As removal has become demonstrably more "definite, immediate and largely automatic," courts have backed away from consideration of the full standard for directness as originally applied and have come to focus almost exclusively on the fact that removal is not imposed by the criminal

$190 \quad$ Id. $\S 238($ c) $(5), 8$ U.S.C. $\S 1228(c)(5)$.

19118 U.S.C. $\$ 3563(\mathrm{~b})(21)$ (2006).

192 Julia Preston, 270 Immigrants Sent to Prison in Federal Push, N.Y. Times, May 24, 2008, at A1; ICE News Release, 297 Convicted and Sentenced Following ICE Worksite Operation in lowa (May 15, 2008), http://www.ice.gov/pi/news/newsreleases/articles/080515waterloo.htm. 193 See, e.g., United States v. Vega-Nava, No. CR 08-1257 (N.D. Iowa May 22, 2008); United States v. Lastor-Gomez, No. CR 08-1141 (N.D. Iowa May 19, 2008).

194 See, e.g., Fruchtman v. Kenton, 531 F.2d 946, 949 (9th Cir. 1976); Michel v. United States, 507 F.2d 461, 465 (2d Cir. 1974) ("The district judge, in our view, has the obligation to ascertain that the consequences of the sentence he imposes are understood. Deportation here, as before, was not the sentence of the court which accepted the plea but of another agency over which the trial judge has no control and for which he has no responsibility."); Daley v. State, 487 A.2d 320, 322 (Md. Ct. Spec. App. 1985). 
court. The Sixth Circuit, for example, in El-Nobani v. United States, ${ }^{195}$ sidestepped the question of automaticity by stating without evidence that "although the INS has been restricted in its ability to grant certain discretionary relief in deportation proceedings, 'there is no indication that the INS has ceased making this sort of determination on a case-by-case basis." 196 In any case, the court went on to hold, "the automatic nature of the deportation proceeding does not necessarily make deportation a direct consequence of the guilty plea. A collateral consequence is one that 'remains beyond the control and responsibility of the district court in which that conviction was entered."'197 Other courts have focused similarly on the nominal independence of the deportation decisionmaker. ${ }^{198}$ In fact, every single federal circuit court of appeals that has held that deportation continues to be a collateral consequence in the wake of the 1996 changes has relied solely on the fact that the final removal order is entered by an agency other than the sentencing court, regardless of how definite, immediate, or automatic the sanction is. ${ }^{199}$ None of these courts has mentioned or addressed the statutory procedures for judicial removal by federal sentencing judges under INA section 238(c)(1), and these decisions were issued prior to the mass judicial removals of the 2008 Agriprocessing case. In the absence of such consideration, these courts have simply stated that removal continues to be imposed by an independent, civil agency and, as such, is collateral.

The forum of the removal decision is presumably a significant factor for these courts because it reflects the independent judgment and action of another decision-making entity which considers factors outside the province of the sentencing court and exercises some independent judgment on factors relating specifically to the question of removal. This intervention presumably assures the court that there is some kind of

195287 F.3d 417 (6th Cir. 2002).

196 Id. at 421 (citing Reno v. Am.-Arab Anti-Discrimination Comm., 525 U.S. 471, 484 n.8 (1999) (making the same statement without citing any factual evidence or explaining any statutory basis for the claim that deportation proceedings continue to be decided on a case-bycase basis despite the new restrictions)).

197 Id. (citing United States v. Gonzalez, 202 F.3d 20, 27 (1st Cir. 2000)).

198 See, e.g., United States v. Amador-Leal, 276 F.3d 511, 516 (9th Cir. 2002) ("[W]hether an alien will be removed is still up to the INS. There is a process to go through, and it is wholly independent of the court imposing sentence.... Removal is not part of the sentence...."); Gonzalez, 202 F.3d at 27 ("However 'automatically' [the defendant's] deportation ... might follow from his conviction, it remains beyond the control and responsibility of the district court in which that conviction was entered and it thus remains a collateral consequence thereof."); Rumpel v. State, 847 So. 2d 399, 401 (Ala. Crim. App. 2002); People v. DeJesus, 819 N.Y.S.2d 442, 44345 (Crim. Ct. 2006) (finding that immigration consequences are collateral despite their definite, automatic nature because they are imposed by an "independent agency").

199 Santos-Sanchez v. United States, 548 F.3d 327, 337 (5th Cir. 2008); Broomes v. Ashcroft, 358 F.3d 1251, 1256 (10th Cir. 2004); El-Nobani, 287 F.3d at 421; Amador-Leal, 276 F.3d at 516-17; Gonzalez, 202 F.3d at 27; see also Francis, supra note 67, at 710 (arguing that courts have allowed the certainty and severity of deportation to be trumped by the fact that it is imposed by a court other than the sentencing court). 
substantive process in which other considerations are taken into account, that is, the imposition of the consequence is not automatic, but meaningfully considered in an appropriate setting. In the absence of some meaningful independent consideration, it is difficult to see how or why this single factor should carry all the weight of determining whether a consequence is the direct result of a criminal court's action, unless it is simply a reflection of the fact that courts have been unwilling to break with longstanding precedent that has denied constitutional significance to this consequence or that they fear the practical implications of giving it constitutional protection.

As we have seen, the link between criminal and immigration enforcement continues to grow stronger with each passing year, and it can no longer be said categorically that noncitizens convicted of crimes have the benefit of a separate administrative removal hearing "wholly independent of the court imposing sentence." 200 Indeed, in the clearest cases-those involving judicial removal under INA section 238(c)-the removal order is, in fact, entered by the sentencing court. ${ }^{201}$ The melding of the criminal with the immigration process in these cases has gone the last step in erasing any distinction between the criminal and immigration courts; the immigration consequence is imposed as part of the criminal process itself, by the same judge who enters the conviction and the sentence. ${ }^{202}$ There is, of course, no separate civil proceeding at all, and the analysis of the circuit courts of appeal that have relied on this single factor collapses in the face of the exercise of judicial removal power.

The Ninth Circuit has directly addressed the question of whether judicial deportation under INA section 238 (c) is a criminal or civil proceeding, though in a different procedural setting. The question arose in a petition by a former criminal defendant for attorneys' fees under the Equal Access to Justice Act (EAJA) for his successful argument in opposition to judicial deportation at criminal sentencing. ${ }^{203}$ The petitioner

200 Amador-Leal, 276 F.3d at 516.

201 See, e.g., United States v. Lastor-Gomez, No. CR 08-1141 (N.D. lowa May 19, 2008). This case is one of 297 in which guilty pleas were entered and defendants were sentenced within ten days in May 2008. ICE News Release, supra note 192. In each case, the district court, as part of the sentencing, entered a stipulated judicial order of removal pursuant to INA section 238(c)(5), 8 U.S.C. $\$ 1228(c)(5)(2006)$.

202 See Ethan Venner Torrey, "The Dignity of Crimes": Judicial Removal of Aliens and the Civil-Criminal Distinction, 32 CoLuM. J.L. \& SOC. ProBs. 187, 199-200 (1999) (arguing against the use of judicial deportation on the grounds that it would so enmesh the criminal and immigration processes as to require constitutional protections in both). "If deportation decisions are embodied in plea agreements, however, as permitted by [INA section $238(\mathrm{c})]$, then deportation would become part of 'the sentence of the court which accepted the plea,' and would emphatically not be the decision of 'another agency over which the trial judge has no control and for which he has no responsibility:' Deportation would therefore be a direct consequence of a criminal conviction." Id. (quoting Michel v. United States, 507 F.2d 461, 465 (2d Cir. 1974); United States v. George, 869 F.2d 333, 337 (7th Cir. 1989)).

203 United States v. Soueiti, 154 F.3d 1018 (9th Cir. 1998). 
argued that EAJA fees were appropriate because deportation proceedings are civil in nature. The Ninth Circuit disagreed and held that in the context of a judicial deportation (that is, deportation during criminal sentencing), the deportation determination itself becomes criminal in nature:

\begin{abstract}
In the procedural context of this case, [deportation] was criminal. That context was a decision whether to order deportation as part of a criminal sentencing proceeding.... The procedure for sentencing a criminal defendant is criminal, regardless of whether some portions of the judgment, such as deportation or restitution, might also be imposed in a civil proceeding. ${ }^{204}$
\end{abstract}

Interestingly, the court apparently did not find this to be a difficult question, finding unanimously that the case was appropriate for resolution without oral argument. 205

Judicial removal is the clearest illustration of the melding of the criminal and immigration processes for those convicted of crimes, but the other procedural permutations available to individuals convicted of aggravated felonies lead just as inexorably to an order of removal. For nonpermanent residents subjected to "administrative" or "ministerial" removal, the sentencing judge may not order removal directly, but he or she is the last one to make a substantive decision relevant to removal. There is no other judicial or hearing process in any branch of government to determine if these individuals should be removed. Rather, a DHS employee simply confirms that the individual has an aggravated felony conviction and, because of the conclusive presumption of deportability and disqualification from any relief (both of which arise directly from the fact of the conviction), may order the individual removed without a hearing of any kind. 206

Even for those individuals who are still given an immigration hearing, the decision-maker there is also often restricted to an essentially bureaucratic or clerical function of connecting the dots to a preordained outcome. In the case of an individual with an aggravated felony conviction, the immigration judge is as bound by operation of law as the DHS employee imposing "administrative" removal orders to enter an order of removal. There is no room for a finding that the individual is not

$204 \quad I d$ at 1019.

205 Id. at 1018 n.*. On similar grounds, the Second Circuit had previously held that proceedings to determine whether a criminal sentencing judge would issue a judicial recommendation against deportation under pre-1990 law were part of the criminal proceeding and therefore subject to a Sixth Amendment guarantee of effective assistance of counsel. Janvier v. United States, 793 F.2d 449, 452 (2d Cir. 1986).

206 INA $\S 238($ b), 8 U.S.C. $\S 1228(b)-(c)(2006)$. 
removable 207 and simply no legal option for the court to exercise its discretion and find her eligible for some form of relief from removal. 208

Given that the significance of the independent forum for the removal decision is presumably that it implies the existence of a separate process in which factors relevant to the appropriateness of removal can be taken into account, can it be meaningfully said that a removal hearing with a preordained outcome constitutes a separate decision-making process? Addressing this question, the Second Circuit, in United States v. Couto, ${ }^{209}$ dismissed the role of an immigration court following an aggravated felony conviction as "ministerial." The court observed that "when an event is a certain consequence of a [prior] decision by a [sentencing] court, it is meaningless to say that the [sentencing] court did not ordain that event; any action by other institutions [is] purely ministerial." 210 As discussed above, the court found in Couto and in the subsequent case of Zhang $v$. United States 211 that it did not have to decide the issue of directness, but observed in dicta that it found merit in the argument that there was no longer any independent court or body with power to affect the deportation outcome in the case of aggravated felonies, and that these individuals have lost any meaningful opportunity for a separate tribunal to make a determination other than an order of removal. 212

\section{Removal as a Criminal Sanction}

\section{A. Implications of Acknowledging Removal as Punishment for Crime}

If courts acknowledge that the removal of lawful permanent residents and other authorized noncitizens for criminal behavior constitutes punishment and a direct consequence of a conviction, important constitutional rights for noncitizen defendants will be implicated. These include the right to trial and the effective assistance of counsel guaranteed by the Sixth Amendment, as well as the right to be free of cruel and unusual punishment under the Eighth Amendment. In the context of plea bargaining, the Constitution and Rule 11(b) of the Federal Rules of Criminal Procedure 213 would require that defendants be advised that removal would be a consequence of certain pleas in order to knowingly and voluntarily waive their Sixth Amendment right to trial. The Eighth

\footnotetext{
207 Id. $\S 238(\mathrm{c}), 8$ U.S.C. $\S 1228(\mathrm{c})$.

208 See supra Section III.B regarding the ineligibility of individuals with aggravated felony convictions for any discretionary relief from removal.

209311 F.3d 179 (2d Cír. 2002).

210 Id. at 190 n.10.

211506 F.3d 162 (2d Cir. 2007).

212 Id. at 167; Couto, 311 F.3d at 190.

213 FED. R. CRIM. P. 11(b).
} 
Amendment would require that removal be imposed only in such circumstances that it would not be so disproportionate to the crime committed as to be considered cruel and unusual. The practical difficulties of administering this change in procedure and substantive rights would be substantial.

Courts have taken on revolutions in criminal practice in the past, such as in the wake of Gideon v. Wainwright, ${ }^{214}$ when the Supreme Court read the Sixth Amendment to require the appointment of counsel for indigent criminal defendants. Surely, the logistical difficulty of ensuring constitutional rights is no argument for not doing so.

Nevertheless, it is difficult as a practical matter to envision how state and federal criminal courts around the country would accommodate the recognition of these constitutional rights relating to immigration consequences. The analysis of the exact immigration consequences of a conviction is complex and technical. While the consequences of an aggravated felony conviction are clear and automatic, there is sometimes a question of law as to whether an offense falls within that category or another, such as a crime involving moral turpitude. In non-aggravated felony cases, even if there is a finding of removability based on the conviction, there is often a question of whether the individual may qualify for some relief from removal. That eligibility depends in turn not only on the nature of the conviction, but also on the individual defendant's specific immigration status and history, as well as any prior criminal history. Expertise in matters at the intersection of criminal and immigration law is, frankly, not nearly widespread enough in the bar or on the bench to accommodate this need.

\section{B. Is Removal an Effective and Appropriate Sanction for Crime?}

There is no reason to conclude automatically that it is either desirable or undesirable to attach an inevitable sanction of removal for designated criminal activity. As Stephen Legomsky points out, a combination of civil and criminal penalties is imposed in a variety of contexts, ${ }^{215}$ including tort liability and civil forfeiture or penalties for conduct already punished as a crime. ${ }^{216}$ Given the substantial practical difficulties that would arise from requiring constitutionally sufficient advice to be given to defendants on the issue of immigration consequences in the criminal context, though, it is appropriate to ask whether this particular system of double sanctions serves important interests in an appropriate way and is thus worth the

214372 U.S. 335 (1963)

215 Legomsky, supra note 46 , at 519.

216 See also cases discussed supra Subsection I.B.2 (regarding the penal nature of sanctions in civil proceedings). 
considerable trouble of accommodating the constitutional concerns it raises. For reasons at least of proportionality and equity among similar offenders, ${ }^{217}$ I conclude that automatic removal is not a justifiable or appropriate sanction for the broad range of convictions to which it now applies. It is applied without reference to the true severity of the crime or the myriad other factors that traditional sentencing courts consider in tailoring punishment to a crime, and it results in grossly unequal sanctions for similarly situated offenders, which raises serious fairness issues.

Removal could best be justified by two of the classic purposes of punishment: incapacitation and retribution. The DHS publicizes its program of deporting convicted individuals as a public safety measure, describing "criminal aliens" as among the "worst of the worst." 218 It argues that removing individuals who have committed crimes reduces the likelihood that others in the community will be victimized by crime. This is essentially an argument for the incapacitation justification of punishment-that the punishment keeps the individual from committing another crime. Incapacitation of offenders has become a dominant theme in the American response to crime generally, and has led us as a nation to a model of crime control centered on the incarceration of large numbers of people. ${ }^{219}$ Rather than working on any theories of rehabilitation, this approach operates on the assumption that once an individual has committed a crime, society is better off spending its resources to separate and protect itself from the individual, rather than to reintegrate that individual into the fabric of the community. The removal (and subsequent bar to readmission) of noncitizens convicted of crimes is a very satisfying outcome within this theoretical framework, because (assuming no illegal reentry) it provides a permanent separation of the wrongdoer from the community, thereby providing maximum protection to society. 220 The argument within this framework could be that, given a conflict of interests, we would choose to value the interests of those individuals most integrated into our community (citizens) at the expense of those who are

217 For a further discussion of these and other costs of the current system of crimerelated deportations, see Legomsky, supra note 46, at 519.

218 ICE FISCAL YEAR 2008 ANNUAL REPORT, supra note 181, at 3.

219 See, e.g., AM. BAR ASS'N, JUSTICE KENNEDY COMM'N, REPORTS WITH RECOMMENDATIONS TO THE ABA HOUSE OF DELEGATES (2004), available at http://www.abanet.org/crimjust/kennedy/JusticeKennedyCommissionReportsFinal.pdf; PEw CTR. ON THE STATES, ONE IN 100: BEHIND BARS IN AMERICA 2008 (2008), available at http://www.pewcenteronthestates.org/uploadedFiles/One\%20in\%20100.pdf.

220 This strategy begs the question, of course, of the effect of these deportations on the receiving communities. One striking and problematic example of this strategy's results is the explosion of transnational gangs in Central America and the United States with the deportation of individuals who were gang members in Los Angeles and other American cities. See, e.g., ClaRE

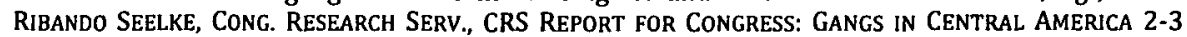
(2008), available at http://www.fas.org/sgp/crs/row/RL34112.pdf. The high number of prosecutions each year for illegal reentry after removal also puts in question the removal strategy's true effectiveness. 
not citizens and thus not full members of the community (noncitizens subject to removal).

The other most plausible justification for removal as punishment is retribution, the idea that it is just to punish a wrongdoer simply because wrongdoing deserves punishment. Under this rationale, it is morally fitting that a wrongdoer should get his "just deserts" - that is, that he "should suffer in proportion to his wrongdoing." 221 This justification would seem to fit with the automatic nature of removal for aggravated felonies and the sanction's indifference to the consequences of removal for the individual or those around him.

Both incapacitation and retribution, though, are undermined as justifications for automatic removal by its most striking feature as a form of punishment-its complete divergence from the criminal system of graduated and proportional penalties in sentencing. As Juliet P. Stumpf points out in her thoughtful article, Penalizing Immigrants, criminal law uses a complex system of graduated sanctions designed to fit the severity of a crime's punishment to the seriousness of the criminal behavior. ${ }^{222}$ This system takes into consideration the circumstances and context of the crime, the history of the defendant, and the impact on the victim. Its tools include fines, community service, suspended sentences, parole, probation, diversionary programs, varying lengths of incarceration, and even the death penalty. ${ }^{223}$ In one of the few ways immigration law has failed to move closer to the criminal enforcement model, however, immigration law still allows for only one sanction for almost any violation-removal. ${ }^{224}$

Automatic removal is not calibrated in any way to the severity of the underlying criminal offense. As a punishment, it is a very blunt instrument. It is as if the criminal sentencing system were to impose a life sentence without parole for any conviction, no matter how minor the conduct or justifiable the circumstances surrounding the criminal activity. Removal is a severe sanction, especially for a lawful permanent resident who will be forced to leave behind all ties to the community in which she has made her home, including family, career, business, property, friendships, and community activities and connections. As an automatic sanction for an aggravated felony, removal is the same for a murderer given a life sentence

221 See, e.g., Leo ZaIBERT, PUNISHMENT AND RETRIBUTION 11 (2006) (quoting JOHn RaWLS, Two Concepts of Rules, in COLLECTED PAPERS 21 (Samuel Freeman ed., 2001)).

222 Stumpf, supra note 47 , at 264-65.

223 See id. at 265.

224 Id. at 264 . Stumpf proposes a system of graduated penalties in the immigration context that would take into account the nature and facts surrounding the violation as well as the individual's status and stake in the United States. Possible sanctions might include an extension of the waiting period for eligibility to naturalize, a finding and stay of removal (analogous to a suspended sentence), a fine, or a period of probation in which any further violation would result in deportation. 
as for a shoplifter who received a suspended sentence of one year (both of whom are considered aggravated felons by the immigration law).

One of the key principles of retribution is that the punishment of the wrongdoer must be in proportion to his desert, his moral responsibility for the wrong. ${ }^{225}$ Any system that automatically sanctions a murderer and a shoplifter equally and without regard for the circumstances of the offenses cannot be said to be proportional, and this disregard for proportionality in turn completely undermines any meaningful justification of removal under the very definition of retribution.

Incapacitation, on the other hand, is a utilitarian justification for punishment, and is appropriate when the cost to the community of incapacitation is outweighed by the additional safety accorded the community through the absence of the wrongdoer. The widespread urge in American society in the past few decades to "wall off" offenders fails to take into account the many and complex connections these individuals have in our communities and the cost-to the individual and to members of the community - of thwarting or cutting off those connections. In the case of noncitizens, the current regime of automatic removal includes no meaningful review of the individual's situation in the context of the removal decision and thus has no mechanism to distinguish between different levels of culpability (and possible future danger to the community) or between different levels of connection between the individual and the community. Under the current system, a newly arrived undocumented person with no ties to the community is treated the same as a longtime permanent resident who has lived most of his life in the United States and has extensive connections with U.S. citizens, lawful permanent resident family members, and other members of the community. In fact, permanent residents often do have extensive ties to family and community that are as important for the family and community members as they are for the individual. Thus, it is often the U.S. citizen or permanent resident children and spouse who are hurt most by the deportation of their breadwinner.

This failure to distinguish or value varying levels of connection to the community among immigrants reveals a philosophy of immigration that maintains that all noncitizens are present in the country equally at the mercy of the government, with no vested interest built through time, connections, or integration into society. This understanding fails to acknowledge the investment that lawful permanent residents and others have and build over time in our communities.

225 MiChaEl MoORE, Placing Blame 88 (1997); John Rawls, Two Concepts of Rules, 64 PhIL. REv. 3, 4-5 (1955) ("That a criminal should be punished follows from his guilt, and the severity of the appropriate punishment depends upon the depravity of his act."). 
If we acknowledge the investment of these longtime residents in our community, it becomes clear that the sanction of removal, added to whatever sanction the criminal court has already imposed for a conviction, is an additional and very severe penalty. The inequality between that double sanction and the criminal sanction alone imposed on the citizen is manifest. The status of citizenship is the only distinction between a citizen convicted of shoplifting and a lawful permanent resident with the same conviction who has resided most of his or her life in the United States and has significant community and family ties. The reality of the practical, familial, economic, social, and psychological effects of permanent banishment from the United States on either individual would be very similar, yet we would be appalled at the idea of banishment as a punishment for the citizen. If we look beyond the labels of "immigrant" and "citizen" and fairly assess the effect that removal has on permanent residents and on their vested interest in our society, we may very well find that the thin line of citizenship or national origin cannot bear the weight of such a distinction. The inequality between the two sanctions is manifestly unjust.

\section{Conclusion}

The last two decades have seen changes in the immigration law and the infrastructure of immigration enforcement that have fatally undermined the longstanding legal constructions that have held deportation to be a "collateral" and "remedial" consequence of a conviction for lawfully authorized noncitizens. These changes render removal orders the automatic result of aggravated felony convictions and have integrated immigration into the criminal process to the extent that many sentencing courts are participating directly and indirectly in facilitating removal; some are now even entering orders of removal directly. In the case of lawful permanent residents and other authorized noncitizens, it is the conviction alone that gives rise to deportability, and in this context, removal functions as punishment for wrongdoing. Courts should recognize this evolution and hold that immigration consequences have become the direct consequences of an aggravated felony conviction and that they follow from the fact of the conviction alone, automatically and without opportunity for discretionary relief or meaningful adjudicatory proceedings in another forum.

Even if the sanction of removal for aggravated felony convictions continues to be labeled civil or collateral, it would be appropriate to guarantee a level of procedural protections in criminal court in recognition of the unique severity of the removal sanction and its currently automatic imposition. Our constitutional guarantees in the criminal area are grounded in an unwillingness to impose severe penalties (involving loss of 
liberty and separation from family among others) without substantial procedural protections. This underlying commitment to the protection of individual liberties should not vanish with the labeling of a proceeding as "civil." Where a civil sanction approaches or even surpasses the severity of criminal penalties, our concerns for proportionality and individual protection warrant requiring procedural guarantees analogous to criminal proceedings, including the right to be advised specifically of the nature of the consequence and the guarantee that the sanction will not be grossly disproportionate to the offense. Such is the case with the sanction of removal. ${ }^{226}$

Procedural guarantees regarding immigration would not be unique in proceedings that have been denominated as civil. In State $v$. Bellamy, 227 the New Jersey Supreme Court held that, given the severity of civil commitment, fundamental fairness required that a defendant understand that he faced possible commitment proceedings as a sex offender before he pled guilty to a predicate sex offense, even though the court acknowledged that the separate commitment proceedings were civil and collateral in nature. The court stated, "'It matters little if the consequences are called indirect or collateral when in fact their impact is devastating," 228

As discussed above, the ABA Standards on Collateral Sanctions and Discretionary Disqualification take the position that the broad range of collateral consequences of criminal convictions, including immigration consequences, should be integrated into the criminal process and be considered meaningfully as part of the package of sanctions being imposed at sentencing. The Standards would require that these collateral consequences be taken into account by the sentencing judge to ensure that the "totality of the penalty" is not unduly severe. 229

Given the limited human, professional, and other resources at the disposal of criminal courts, the practical challenges of instituting such changes are myriad. At the same time, removal is not truly justifiable and does not function well as a one-size-fits-all punishment for criminal conduct, as it is not tailored in any way to the severity of the crime, and it gives rise to serious problems of equity between otherwise similarly situated citizen and longtime permanent resident offenders. Thus, rather than requiring our criminal trial courts to make constitutional accommodations for an ill-fitting and often disproportionate punishment, Congress could resolve the constitutional dilemma by enacting a substantial revision of those aspects of our immigration law which relate

226 On the similarity of removal to criminal sanctions, see Francis, supra note 67 , at 714.

227835 A.2d 1231 (N.J. 2003).

228 Id. at 1238 (quoting State v. Heitzman, 527 A.2d 439, 441 (N.J. 1987) (Wilentz, C.J., dissenting)).

229 ABA StANDaRds on Collateral Sanctions, supra note 41, at Standard 19-2.4. 
to crimes and which currently result in the automatic imposition of removal as a sanction for the very wide range of offenses characterized as aggravated felonies. Such reform would restore meaningful reality to individualized discretionary decision-making, proportionality, and discretion in the far-reaching and life-changing decision whether an individual should be deported for having committed a particular offense. 
